\title{
Water and dissolved gas geochemistry at Coatepeque, Ilopango and Chanmico volcanic lakes (El Salvador, Central America)
}

\author{
J. Cabassi a,b,*, F. Capecchiacci ${ }^{\text {a,b }}$, F. Magi ${ }^{\text {a,c }}$, O. Vaselli ${ }^{\text {a,b }}$, F. Tassi ${ }^{\text {a,b }}$, F. Montalvo $^{\text {d }}$, I. Esquivel ${ }^{\text {d }}$, \\ F. Grassa ${ }^{\mathrm{e}}, \mathrm{A}$. Caprai ${ }^{\mathrm{f}}$ \\ a Dipartimento di Scienze della Terra, University of Florence, Via G. La Pira 4, 50121 Florence, Italy \\ b CNR - Istituto di Geoscienze e Georisorse, Via G. La Pira 4, 50121 Florence, Italy \\ c Dipartimento di Scienze della Terra, University of Pisa, Via Santa Maria 53, 56126 Pisa, Italy \\ d Ministerio de Medio Ambiente y Recursos Naturales, Kilómetro 51⁄2 Carretera a Santa Tecla, calle y colonia Las Mercedes, San Salvador, El Salvador \\ e Istituto Nazionale di Geofisica e Vulcanologia, Sezione di Palermo, Via Ugo La Malfa 153, 90146 Palermo, Italy \\ ${ }^{\mathrm{f}}$ CNR - Istituto di Geoscienze e Georisorse, Via G. Moruzzi 1, 56124 Pisa, Italy
}

\section{A R T I C L E I N F O}

\section{Article history:}

Received 16 January 2019

Received in revised form 17 April 2019

Accepted 18 April 2019

Available online 22 April 2019

\section{Keywords:}

Volcanic lakes

El Salvador

Water geochemistry

Dissolved gas geochemistry

Stable isotopes

Unusual chemical compositions

\begin{abstract}
A B S T R A C T
Coatepeque (on the E slope of Santa Ana Volcano), Ilopango (inside Ilopango Caldera) and Chanmico (associated with San Salvador Volcano) are volcanic lakes in El Salvador, showing a thermocline at a relatively shallow depth (from 30 to $40 \mathrm{~m}$, from 20 to $40 \mathrm{~m}$ and from 5 to $15 \mathrm{~m}$ depth, respectively) and anoxic conditions below 33,24 and $4 \mathrm{~m}$ depth, respectively. The $\mathrm{Na}^{+}-\mathrm{Cl}^{-}$composition of the Coatepeque and Ilopango lakes, displaying TDS values up to 1226 and $1216 \mathrm{mg} / \mathrm{L}$, respectively, is likely due to hydrothermal fluids that feed these two lakes,

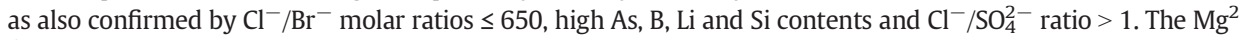
${ }^{+}-\mathrm{HCO}_{3}^{-}$water composition of Lake Chanmico, whose TDS values were between 566 and $856 \mathrm{mg} / \mathrm{L}$, suggests water-rock interaction processes with mafic/ultramafic rocks variably affected by serpentinization processes, which produced high $\mathrm{Mg}^{2+}$, Si and B concentrations. Waters at depth were characterized by the presence of $\mathrm{CO}_{2}$ from an extra-lacustrine source, as suggested by $\delta^{13} \mathrm{C}_{-}-\mathrm{CO}_{2}$ values significantly less negative than those typically related to biogenic processes, albeit this gas was found in smaller quantities when compared to those recorded in other meromictic lakes hosted in quiescent volcanic systems (e.g. Lake Kivu in DRC, Monticchio, Albano and Averno lakes in Italy, Hule and Rio Cuarto lakes in Costa Rica, Lake Pavin in France). The occurrence of $\mathrm{CH}_{4}$, whose concentrations in Lake Chanmico were up to two orders of magnitude higher than those recorded in Coatepeque and Ilopango lakes, suggests bacterial methanogenesis.
\end{abstract}

(c) 2019 Published by Elsevier B.V.

\section{Introduction}

Volcanic lakes are peculiar natural systems, although they represent a relatively common feature of active and quiescent volcanoes and mostly associated with subduction-related environments, particularly in sub- to tropical areas. They show a large variability in terms of size as they are hosted within maar as well as giant calderas (Rouwet and Tassi, 2014; Varekamp, 2015). The existence and persistence of a volcanic lake are governed by the balance between water inputs (e.g. precipitation, inflows) and outputs (e.g. evaporation, seepage, outlets). Volcanic lakes can be divided into: i) high-activity and medium-activity lakes, where significant amounts of heat and acidic hydrothermal- to magmatic-dominated fluids are released and ii) low activity lakes, i.e. acidic sulfate lakes with TDS $<10 \mathrm{~g} / \mathrm{L}$ or $\mathrm{CO}_{2}$-dominated lakes,

\footnotetext{
* Corresponding author at: Department of Earth Sciences, University of Florence, Via G. La Pira, 4, 50121 Florence, Italy.

E-mail address: jacopo.cabassi@gmail.com (J. Cabassi).
}

characterized by deep fluid inputs at relatively low rate (Pasternack and Varekamp, 1997; Rouwet et al., 2014; Varekamp, 2015). The latter, namely bio-activity lakes (Cabassi et al., 2014), characterized by relatively low temperature and salinity, neutral to slightly acidic $\mathrm{pH}$ and permanent thermal and chemical stratification (Rouwet et al., 2014), are particularly prone to the development of $\mathrm{CO}_{2}\left(\mathrm{CH}_{4}\right)$-rich gas reservoirs at depth, significantly mediated by bacterial activity (e.g. Caliro et al., 2008; Tassi et al., 2009; Cabassi et al., 2013; Tassi and Rouwet, 2014; Tassi et al., 2018a, 2018b). Gas accumulation can eventually trigger limnic eruptions, a typical feature of Nyos-type lakes (e.g. Tassi and Rouwet, 2014; Costa and Chiodini, 2015; Kling et al., 2015; Kusakabe, 2015).

The chemistry of waters from volcanic lakes exhibits large variations, i.e. from meteoric-like to hyper-saline and acidic, strictly depending on: i) rate of input from the underlying volcanic-hydrothermal system; ii) input of meteoric water; iii) activity of microbial populations along the water column; iv) interactions with different types of rocks (Varekamp, 2015; Paternoster et al., 2016). Anion concentrations in 


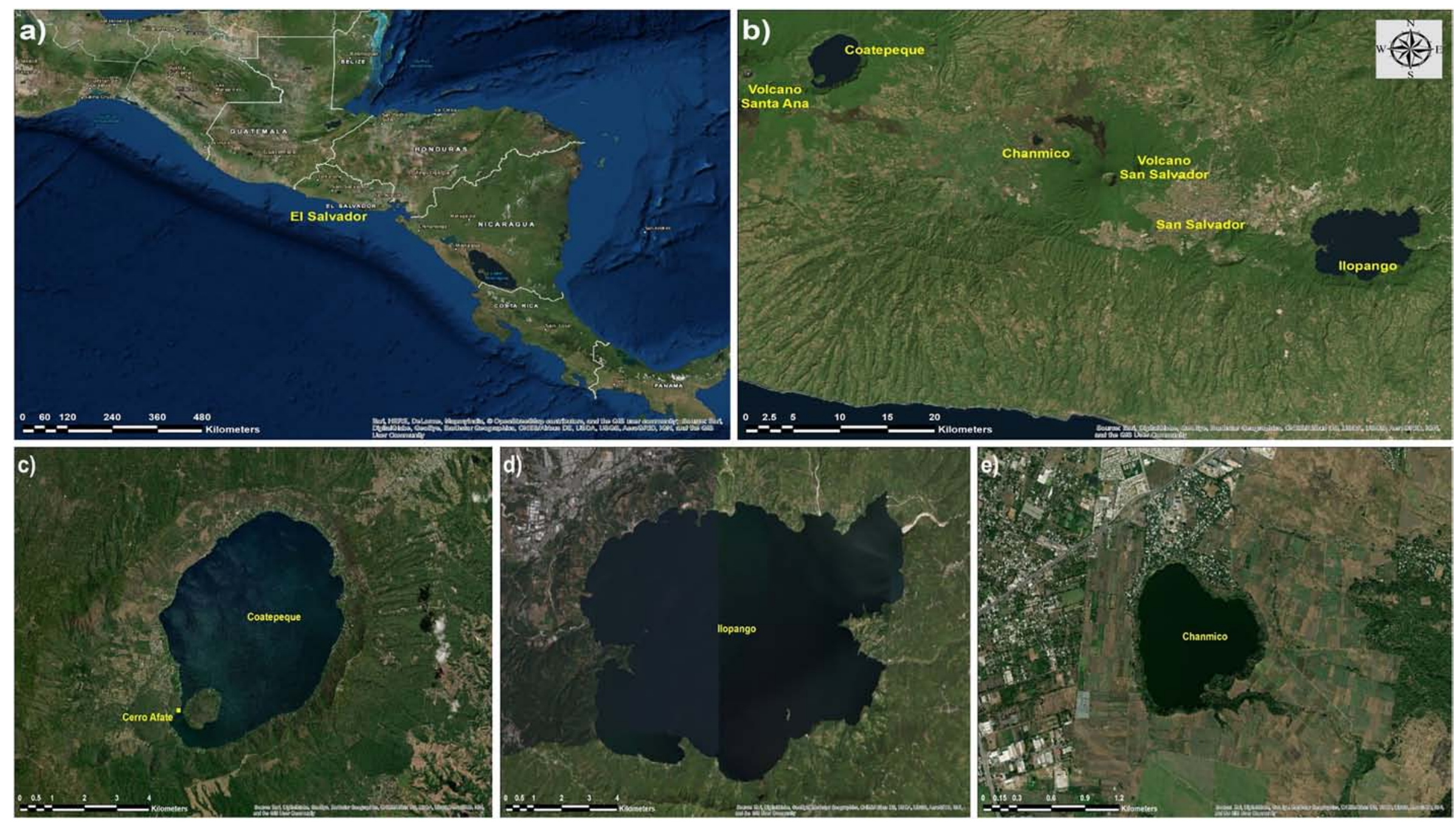

Fig. 1. a-e - Location of El Salvador (a) and the volcanic lakes of Coatepeque, Ilopango and Chanmico within the Central-American state (b). Aerial views of Coatepeque (c), Ilopango (d) and Chanmico (e) lakes. 


\section{COATEPEQUE}
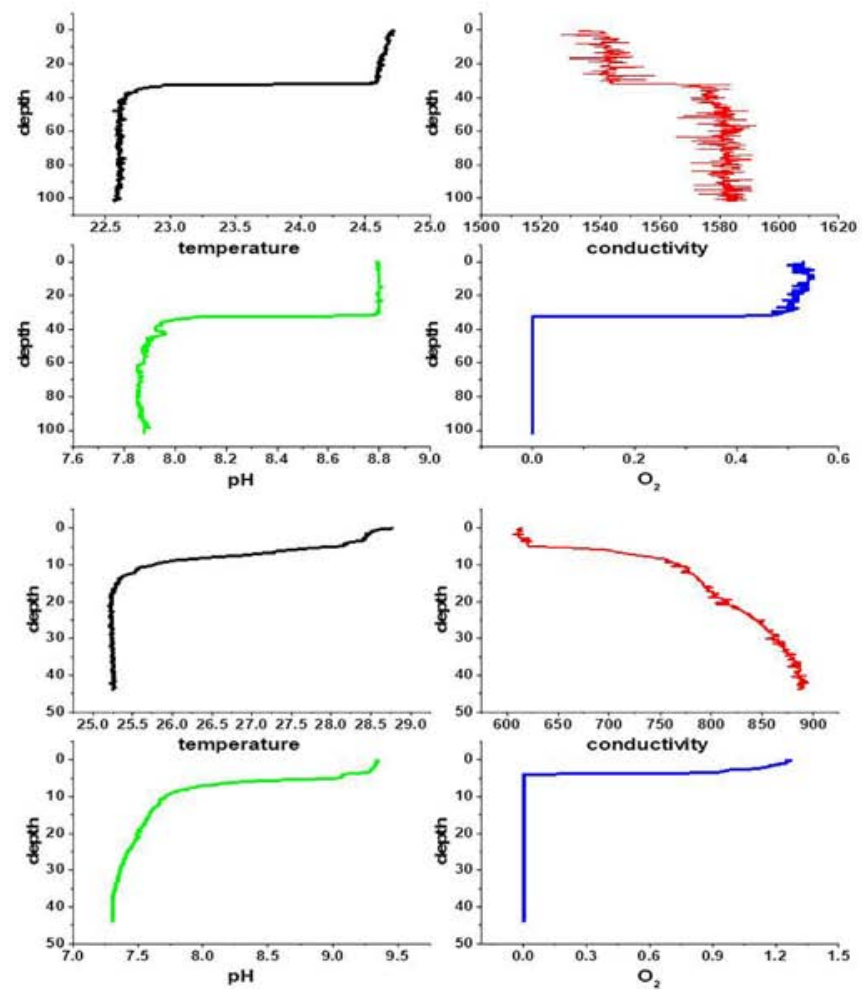

CHANMICO
ILOPANGO

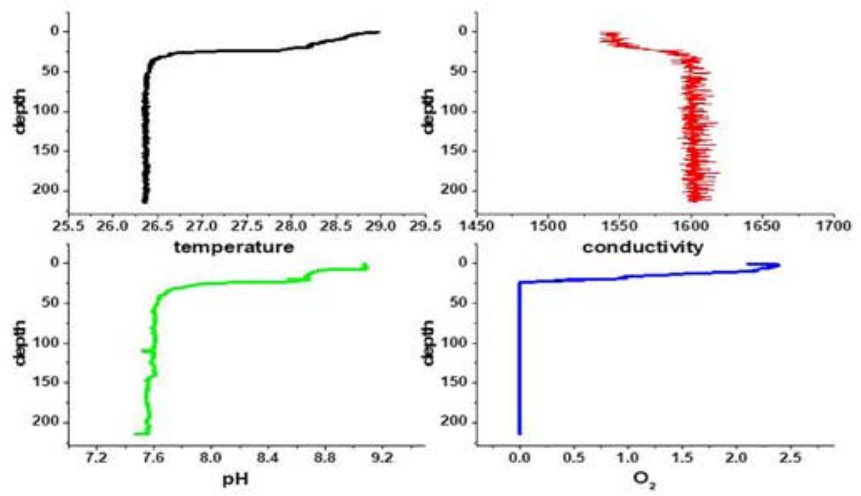

\section{Multi-parametric probe: vertical profiles}

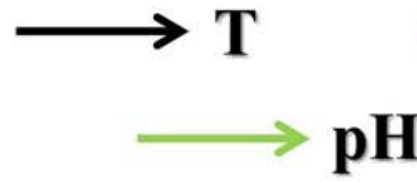

pH

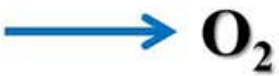

Fig. 2. Vertical profile of temperature $\left({ }^{\circ} \mathrm{C}\right.$ ), conductivity (EC, in $\mathrm{mS} / \mathrm{cm}$ ), $\mathrm{pH}$, dissolved $\mathrm{O}_{2}$ (in $\mu \mathrm{mol} / \mathrm{L}$ ) for the volcanic lakes of Coatepeque, Ilopango and Chanmico.

volcanic lakes are usually considered as related to dissolution of volcanic-hydrothermal gases (Christenson and Tassi, 2015), though the feeding fluids in quiescent volcanoes mostly consist of $\mathrm{CO}_{2}$ with minor amounts of $\mathrm{Cl}$ - and S-bearing acidic gases (Pasternack and Varekamp, 1997). In contrast, the composition of cations is mostly due to water-rock interaction processes in either groundwater or hydrothermal system below the lakes (Sriwana et al., 2000; Varekamp, 2015). Gases dissolved within the lakes are related to different sources: (i) deep fluid inputs, (ii) air-water exchange through the lake surface, and (iii) metabolic processes of microbial communities (Christenson and Tassi, 2015). Consequently, water and dissolved gas chemistry of volcanic lakes is of paramount importance to obtain insights into the origin and evolution of the fluids entering the lacustrine system (e.g. Rowe et al., 1992; Christenson, 2000; Anzidei et al., 2008).

El Salvador (Central America; Fig. 1a) is a land of volcanoes, being located within the volcanic belt known as Central American Volcanic Front (CAVF) that extends from Guatemala to Costa Rica and is related to the subduction of the Cocos Plate beneath the Caribbean Plate (Corti et al., 2005; Agostini et al., 2006 and references therein). In El Salvador, many lakes are associated with volcanic systems, considered as quiescent or showing moderate hydrothermal activity (Alegria, Apastepeque, Aramuaca, Cuscachapa, Coatepeque, Ilopango, Verde lakes; Rouwet, 2013), or characterized by strong fumarolic emissions (Lake Santa Ana; Bernard et al., 2004; Hernández et al., 2007; Scolamacchia et al., 2010; Colvin et al., 2013; Laiolo et al., 2017). This work focuses on Lake Coatepeque (close to Santa Ana Volcano) and Lake Ilopango (inside the Ilopango Caldera) (Fig. 1b), which are of particular interest for the volcanological community, since they show evidences of fluid inputs from the underlying magmatic-hydrothermal systems (e.g. Mann et al., 2004; Richer et al., 2004; Salazar et al., 2004; FORGAES and SNET, 2006; Aleman Alberto and Guerrero Nolasco, 2007; Lopez et al., 2004, 2009, 2012; Rodriguez et al., 2014; Saxby et al., 2016; Martínez-Hackert et al., 2017; Ambury, 2017). Laguna de Chanmico (associated with the San Salvador Volcano; Fig. 1b) is also investigated, since, to the best of our knowledge, no detailed geochemical information is presently available for this lake, and it is not included in the VOLADA database (Rouwet, 2013; Rouwet et al., 2014). Physicochemical, chemical and isotopic features along the water column from the lake surface to the maximum depth were investigated to understand (i) the processes controlling the chemistry of waters and dissolved gases and (ii) the possible role of microbial activity.

\section{Volcanological and limnological outlines}

Lake Coatepeque (Fig. 1c) is a large crater lake located to the east of the Coatepeque Caldera, being part of the Santa Ana-Izalco-Coatepeque volcanic complex (Lopez et al., 2012). It formed 50-70 ka as a result of a volcanic collapse (Pullinger, 1998). Post-caldera eruptions produced basaltic cinder cones and lava flows near the western margin of the caldera and rhyodacitic lava domes along a NE-SW-oriented fracture. Examples of this activity are the wooded island of Isla de Cabra (or Cerro Grande) and the dome of Cerro Pacho (7-10 ka), the latter characterized by gas and thermal emissions (Pullinger, 1998; FORGAES and SNET, 2006; Rodriguez et al., 2014). The lake has an area of $25.3 \mathrm{~km}^{2}$ and a maximum depth of $115 \mathrm{~m}$ (SNET, 2000) and is hosted within an elliptical-shaped crater with main axes of $\sim 6.9 \mathrm{~km}$ (NE-SW) and $\sim 4.9 \mathrm{~km}$ (NW-SE), respectively. The surface waters of the lake have changed color 5 times in the last twenty years $(1998,2006$, 2012, 2016, and 2017). These episodes were interpreted as due to a flowering of cyanophyte micro-algae that constitute part of the lake's phytoplankton (MARN, 2017).

Lake Ilopango (Fig. 1d) is hosted within the Ilopango Caldera, whose last collapse occurred approximately $1.6 \mathrm{ka}$ (Lopez et al., 2012). In the past $57 \mathrm{ka}$, at least four large silicic explosive eruptions took place in 
Table 1

Temperature, $\mathrm{pH}$, main and minor (in $\mathrm{mg} / \mathrm{L}$ ) and trace (in $\mu \mathrm{g} / \mathrm{L}$ ) species and water and TDIC isotopes along the vertical profiles of the Coatepeque, Ilopango and Chanmico lakes. n.d.: not detected. n.a.: not analyzed.

\begin{tabular}{|c|c|c|c|c|c|c|c|c|c|c|c|c|c|c|c|c|c|}
\hline & $\begin{array}{l}\text { Depth } \\
(\mathrm{m})\end{array}$ & $\begin{array}{l}\text { Temperature } \\
\left({ }^{\circ} \mathrm{C}\right)\end{array}$ & $\mathrm{pH}$ & $\begin{array}{l}\mathrm{HCO}_{3}^{-} \\
(\mathrm{mg} / \mathrm{L})\end{array}$ & $\begin{array}{l}\mathrm{F}^{-} \\
(\mathrm{mg} / \mathrm{L})\end{array}$ & $\begin{array}{l}\mathrm{Cl}^{-} \\
(\mathrm{mg} / \mathrm{L})\end{array}$ & $\begin{array}{l}\mathrm{Br}^{-} \\
(\mathrm{mg} / \mathrm{L})\end{array}$ & $\begin{array}{l}\mathrm{NO}_{3}^{-} \\
(\mathrm{mg} / \mathrm{L})\end{array}$ & $\begin{array}{l}\mathrm{SO}_{4}^{2-} \\
(\mathrm{mg} / \mathrm{L})\end{array}$ & $\begin{array}{l}\mathrm{Ca}^{2+} \\
(\mathrm{mg} / \mathrm{L})\end{array}$ & $\begin{array}{l}\mathrm{Mg}^{2+} \\
(\mathrm{mg} / \mathrm{L})\end{array}$ & $\begin{array}{l}\mathrm{Na}^{+} \\
(\mathrm{mg} / \mathrm{L})\end{array}$ & $\begin{array}{l}\mathrm{K}^{+} \\
(\mathrm{mg} / \mathrm{L})\end{array}$ & $\begin{array}{l}\mathrm{NH}_{4}^{+} \\
(\mathrm{mg} / \mathrm{L})\end{array}$ & $\begin{array}{l}\text { TDS } \\
(\mathrm{mg} / \mathrm{L})\end{array}$ & $\begin{array}{l}\text { As } \\
(\mu \mathrm{g} / \mathrm{L})\end{array}$ & $\begin{array}{l}\text { B } \\
(\mu \mathrm{g} / \mathrm{L})\end{array}$ \\
\hline \multirow[t]{12}{*}{ Coatepeque } & 0 & 24.7 & 8.79 & 323 & 0.67 & 294 & 0.80 & 0.09 & 224 & 25 & 89 & 223 & 40 & n.d. & 1219 & 104 & 970 \\
\hline & 5 & 24.7 & 8.8 & 333 & 0.62 & 258 & 0.91 & 0.02 & 178 & 21 & 83 & 213 & 39 & 0.08 & 1127 & 98 & 1170 \\
\hline & 10 & 24.7 & 8.8 & 325 & 0.83 & 267 & 0.80 & 0.04 & 174 & 21 & 83 & 213 & 38 & n.d. & 1123 & 98 & 1240 \\
\hline & 15 & 24.6 & 8.8 & 342 & 0.62 & 267 & 0.87 & 0.09 & 174 & 22 & 84 & 214 & 39 & 0.10 & 1144 & 94 & 1680 \\
\hline & 20 & 24.6 & 8.8 & 345 & 0.75 & 277 & 0.88 & 0.08 & 186 & 23 & 86 & 224 & 41 & 0.10 & 1184 & 92 & 1970 \\
\hline & 25 & 24.6 & 8.8 & 343 & 0.69 & 267 & 0.93 & 0.02 & 195 & 20 & 84 & 232 & 38 & n.d. & 1181 & 92 & 2200 \\
\hline & 30 & 24.6 & 8.79 & 342 & 0.70 & 239 & 1.0 & 0.04 & 207 & 21 & 85 & 218 & 38 & n.d. & 1152 & 94 & 2680 \\
\hline & 40 & 22.7 & 7.92 & 326 & 0.69 & 271 & 0.93 & 0.06 & 197 & 23 & 85 & 217 & 40 & 0.10 & 1160 & 88 & 2850 \\
\hline & 60 & 22.6 & 7.87 & 358 & 0.69 & 286 & 0.96 & 0.11 & 208 & 26 & 86 & 220 & 40 & 0.14 & 1225 & 93 & 1960 \\
\hline & 80 & 22.6 & 7.85 & 329 & 0.74 & 286 & 0.98 & 0.05 & 208 & 24 & 87 & 223 & 44 & 0.10 & 1203 & 90 & 2110 \\
\hline & 100 & 22.6 & 7.88 & 336 & 0.68 & 285 & 1.0 & 0.04 & 204 & 24 & 85 & 211 & 37 & 0.18 & 1184 & 93 & 2410 \\
\hline & 110 & 22.6 & 7.88 & 357 & 0.65 & 279 & 0.92 & 0.14 & 200 & 25 & 87 & 210 & 38 & 0.10 & 1198 & 94 & 2390 \\
\hline \multirow[t]{13}{*}{ Ilopango } & 0 & 29 & 9.07 & 342 & 0.37 & 375 & 1.2 & 0.08 & 54 & 49 & 15 & 317 & 30 & 0.03 & 1183 & 644 & 7870 \\
\hline & 5 & 28.7 & 9.08 & 340 & 0.60 & 367 & 0.96 & 0.12 & 57 & 50 & 15 & 319 & 32 & 0.16 & 1182 & 631 & 7620 \\
\hline & 10 & 28.5 & 8.73 & 331 & 0.71 & 368 & 1.2 & 0.45 & 59 & 50 & 15 & 313 & 32 & 0.02 & 1170 & 641 & 8240 \\
\hline & 15 & 28.3 & 8.68 & 354 & 0.46 & 347 & 1.1 & 0.56 & 59 & 51 & 15 & 321 & 31 & 0.16 & 1181 & 648 & 8960 \\
\hline & 20 & 28.1 & 8.69 & 347 & 0.40 & 374 & 1.3 & 0.04 & 56 & 49 & 15 & 319 & 31 & 0.50 & 1193 & 629 & 9620 \\
\hline & 25 & 27 & 7.97 & 344 & 0.51 & 351 & 1.1 & 0.09 & 58 & 50 & 15 & 317 & 31 & 0.31 & 1168 & 629 & 8400 \\
\hline & 30 & 26.6 & 7.8 & 349 & 0.48 & 347 & 1.0 & 0.66 & 59 & 49 & 15 & 319 & 34 & 0.06 & 1173 & 633 & 8100 \\
\hline & 40 & 26.4 & 7.66 & 354 & 0.44 & 347 & 0.82 & n.d. & 70 & 51 & 15 & 325 & 32 & 0.40 & 1195 & 639 & 8300 \\
\hline & 70 & 26.4 & 7.61 & 345 & 0.56 & 364 & 1.1 & n.d. & 76 & 51 & 15 & 330 & 33 & 0.41 & 1216 & 633 & 8480 \\
\hline & 100 & 26.4 & 7.6 & 366 & 0.56 & 351 & 1.2 & n.d. & 76 & 50 & 14 & 319 & 31 & 0.26 & 1208 & 632 & 8920 \\
\hline & 140 & 26.4 & 7.61 & 340 & 0.68 & 325 & 1.2 & 0.47 & 68 & 47 & 13 & 305 & 29 & 0.62 & 1130 & 634 & 8400 \\
\hline & 180 & 26.4 & 7.56 & 339 & 0.62 & 346 & 1.2 & 0.24 & 64 & 50 & 15 & 317 & 32 & 0.13 & 1165 & 626 & 8630 \\
\hline & 220 & 26.4 & 7.5 & 330 & 0.70 & 337 & 1.2 & n.d. & 69 & 49 & 14 & 315 & 31 & 0.17 & 1147 & 631 & 8350 \\
\hline \multirow[t]{11}{*}{ Chanmico } & 0 & 28.8 & 9.34 & 310 & 0.33 & 11 & 0.01 & 0.02 & 107 & 19 & 64 & 42 & 12 & 0.47 & 566 & 7.4 & 100 \\
\hline & 5 & 28.1 & 9.02 & 314 & 0.36 & 11 & 0.02 & 0.04 & 111 & 21 & 65 & 42 & 11 & 0.25 & 576 & 6.1 & 210 \\
\hline & 10 & 25.8 & 7.71 & 410 & 0.50 & 13 & 0.01 & 9.5 & 116 & 35 & 74 & 47 & 12 & 4.9 & 721 & 6.1 & 200 \\
\hline & 15 & 25.3 & 7.59 & 417 & 0.33 & 12 & 0.02 & 13 & 109 & 38 & 75 & 46 & 12 & 5.0 & 728 & 8.0 & 190 \\
\hline & 20 & 25.2 & 7.5 & 426 & 0.45 & 13 & 0.02 & 0.55 & 122 & 40 & 76 & 48 & 12 & 5.9 & 745 & 7.1 & 190 \\
\hline & 25 & 25.2 & 7.42 & 461 & 0.47 & 14 & 0.02 & 0.04 & 125 & 44 & 78 & 48 & 13 & 8.0 & 792 & 9.3 & 170 \\
\hline & 30 & 25.2 & 7.36 & 481 & 0.58 & 15 & 0.02 & 0.36 & 110 & 44 & 76 & 46 & 14 & 9.0 & 797 & 9.8 & 170 \\
\hline & 35 & 25.2 & 7.32 & 500 & 0.40 & 15 & 0.02 & 0.50 & 114 & 48 & 80 & 49 & 15 & 10 & 832 & 9.7 & 170 \\
\hline & 40 & 25.2 & 7.3 & 504 & 0.33 & 14 & 0.02 & 0.77 & 104 & 47 & 79 & 48 & 13 & 11 & 822 & 10 & 160 \\
\hline & 45 & 25.2 & 7.3 & 520 & 0.82 & 17 & 0.02 & 0.08 & 119 & 47 & 80 & 48 & 13 & 11 & 856 & 12 & 140 \\
\hline & 47 & 25.2 & 7.3 & 522 & 0.38 & 15 & 0.01 & 0.25 & 112 & 47 & 80 & 48 & 13 & 11 & 848 & 13 & 140 \\
\hline Cerro Afate & 1 & $>60$ & 7.5 & 336 & 0.82 & 528 & 2.0 & 0.65 & 149 & 67 & 38 & 392 & 45 & 1.5 & 1560 & 1243 & 7740 \\
\hline
\end{tabular}


Table 1 (continued)

\begin{tabular}{|c|c|c|c|c|c|c|c|c|c|c|c|c|c|c|c|c|}
\hline & $\mathrm{Ba}(\mu \mathrm{g} / \mathrm{L})$ & $\mathrm{Cd}(\mu \mathrm{g} / \mathrm{L})$ & Co $(\mu \mathrm{g} / \mathrm{L})$ & $\mathrm{Cu}(\mu \mathrm{g} / \mathrm{L})$ & $\mathrm{Fe}(\mu \mathrm{g} / \mathrm{L})$ & $\mathrm{Li}(\mu \mathrm{g} / \mathrm{L})$ & $\mathrm{Mn}(\mu \mathrm{g} / \mathrm{L})$ & $\mathrm{Ni}(\mu \mathrm{g} / \mathrm{L})$ & $\mathrm{Pb}(\mu \mathrm{g} / \mathrm{L})$ & $\mathrm{Sb}(\mu \mathrm{g} / \mathrm{L})$ & $\mathrm{Si}(\mathrm{mg} / \mathrm{L})$ & $\operatorname{Sr}(\mu \mathrm{g} / \mathrm{L})$ & $\mathrm{Zn}(\mu \mathrm{g} / \mathrm{L})$ & $\begin{array}{l}\delta \mathrm{D}-\mathrm{H}_{2} \mathrm{O} \\
\% \text { V-SMOW }\end{array}$ & $\begin{array}{l}\delta^{18} \mathrm{O}-\mathrm{H}_{2} \mathrm{O} \\
\% \text { V-SMOW }\end{array}$ & $\begin{array}{l}\delta^{13} \mathrm{C} \text {-TDIC } \\
\% \text { V-PDB }\end{array}$ \\
\hline \multirow[t]{12}{*}{ Coatepeque } & 8.8 & n.d. & 1.4 & 7.6 & 0.26 & 554 & 4.8 & 0.76 & 14 & 31 & 0.80 & 111 & 3.3 & 4.7 & 1.4 & 0.8 \\
\hline & 8.3 & n.d. & 1.7 & 7.4 & 0.67 & 540 & 4.9 & 0.52 & 16 & 35 & 1.0 & 110 & 1.0 & 3.7 & 1.5 & 0.6 \\
\hline & 8.5 & n.d. & 1.7 & 7.5 & 1.2 & 564 & 4.8 & 1.2 & 16 & 41 & 1.2 & 110 & 1.5 & 4.5 & 1.5 & 0.9 \\
\hline & 7.4 & 0.80 & n.d. & 2.3 & 1.9 & 531 & n.d. & n.d. & 14 & 26 & 0.85 & 102 & n.d. & 3.8 & 1.4 & -0.8 \\
\hline & 7.7 & 0.89 & n.d. & 2.2 & 1.8 & 521 & n.d. & n.d. & 16 & 36 & 0.84 & 101 & 0.13 & 4.4 & 1.5 & 0.3 \\
\hline & 7.5 & 0.95 & 0.23 & 1.8 & 0.68 & 509 & n.d. & 0.04 & 18 & 42 & 0.84 & 101 & 0.69 & 2.7 & 1.5 & 0.9 \\
\hline & 7.6 & 0.89 & 0.29 & 1.8 & 0.68 & 514 & n.d. & 0.32 & 22 & 41 & 0.90 & 101 & 0.23 & 2.6 & 1.4 & 0.6 \\
\hline & 7.4 & 0.82 & n.d. & 1.6 & 1.1 & 546 & n.d. & n.d. & 0.36 & 10 & 0.84 & 107 & n.d. & 4.6 & 1.5 & 1.5 \\
\hline & 11 & 0.72 & n.d. & 1.5 & 1.0 & 558 & n.d. & n.d. & 2.2 & 16 & 1.6 & 136 & 5.3 & 3.4 & 1.5 & -0.9 \\
\hline & 8.2 & 0.83 & n.d. & 2.7 & 1.3 & 537 & n.d. & n.d. & 4.6 & 15 & 0.97 & 114 & 0.99 & 3.0 & 1.5 & -0.9 \\
\hline & 14 & 0.83 & n.d. & 4.0 & 3.7 & 559 & n.d. & n.d. & 4.1 & 23 & 1.5 & 136 & 6.6 & 2.9 & 1.4 & -1.3 \\
\hline & 12 & 0.79 & n.d. & 3.3 & 1.0 & 544 & n.d. & n.d. & 7.0 & 26 & 1.6 & 137 & 4.2 & 1.4 & 1.4 & -1.3 \\
\hline \multirow[t]{13}{*}{ Ilopango } & 84 & 0.62 & 1.6 & 8.3 & 0.87 & 665 & 4.8 & 0.52 & 18 & 27 & 7.2 & 271 & 0.69 & -2.1 & 1.1 & -1.9 \\
\hline & 81 & 0.28 & 1.7 & 7.9 & n.d. & 651 & 4.8 & 0.47 & 20 & 34 & 7.1 & 260 & 6.6 & -2.5 & 1.1 & 3.6 \\
\hline & 82 & 0.61 & 2.1 & 7.7 & n.d. & 639 & 4.7 & 1.0 & 25 & 39 & 7.1 & 262 & 5.3 & -2.2 & 1.1 & 3.0 \\
\hline & 82 & 0.58 & 2.7 & 7.5 & 1.5 & 665 & 4.8 & 2.3 & 25 & 47 & 7.2 & 264 & 4.2 & -2.5 & 1.2 & 2.9 \\
\hline & 80 & 0.79 & 2.9 & 7.5 & 0.57 & 629 & 4.7 & 1.8 & 27 & 50 & 6.9 & 261 & 2.4 & -2.9 & 1.2 & 2.5 \\
\hline & 81 & 0.29 & 1.0 & 7.4 & n.d. & 667 & 4.7 & 0.44 & 3.6 & 10 & 7.4 & 275 & 5.0 & -2.6 & 1.1 & 2.1 \\
\hline & 84 & 0.23 & 1.1 & 7.2 & 0.18 & 676 & 13 & 0.30 & 5.1 & 14 & 8.8 & 277 & 7.7 & -2.4 & 1.1 & -0.3 \\
\hline & 81 & 0.32 & 1.1 & 7.3 & 1.6 & 692 & 11 & 0.14 & 5.6 & 17 & 9.5 & 278 & 5.6 & -2.4 & 1.1 & 0.2 \\
\hline & 76 & 0.24 & 1.2 & 7.2 & 0.29 & 691 & 4.8 & 0.23 & 8.2 & 18 & 9.6 & 275 & 8.8 & -2.5 & 1.1 & 0.1 \\
\hline & 75 & 0.20 & 1.1 & 7.4 & n.d. & 688 & 4.8 & 0.87 & 11 & 22 & 9.6 & 274 & 8.1 & -3.1 & 1.1 & -0.2 \\
\hline & 76 & 0.07 & 1.2 & 7.6 & 3.4 & 680 & 4.8 & 0.43 & 10 & 27 & 9.5 & 276 & 6.4 & -3.1 & 1.3 & -0.4 \\
\hline & 78 & 0.33 & 1.3 & 7.7 & n.d. & 654 & 4.7 & 0.50 & 10 & 32 & 7.8 & 270 & 5.3 & -2.6 & 1.4 & 0.9 \\
\hline & 78 & 0.30 & 1.3 & 7.8 & n.d. & 664 & 4.7 & 0.36 & 13 & 31 & 7.9 & 270 & 4.0 & -2.9 & 1.3 & 2.5 \\
\hline \multirow[t]{11}{*}{ Chanmico } & n.d. & 0.32 & n.d. & 1.6 & 5.8 & 8.5 & n.d. & n.d. & 6.6 & 21 & 21 & 59 & 0.23 & -7.2 & 0.5 & 0.5 \\
\hline & n.d. & 0.35 & n.d. & 1.6 & 0.61 & 6.1 & 14 & n.d. & 6.9 & 28 & 20 & 57 & 4.4 & -10.6 & 0.3 & -0.8 \\
\hline & 2.0 & 0.37 & n.d. & 1.1 & 7.4 & 6.5 & 323 & n.d. & 13 & 29 & 23 & 98 & n.d. & -15.1 & -0.6 & -4.3 \\
\hline & 3.8 & 0.36 & n.d. & 1.0 & 6.6 & 6.1 & 303 & n.d. & 11 & 33 & 24 & 111 & n.d. & -17.6 & -1.0 & -4.6 \\
\hline & 5.0 & 0.35 & n.d. & 1.1 & 4.5 & 5.4 & 299 & n.d. & 14 & 35 & 23 & 115 & n.d. & -17.1 & -1.1 & -3.8 \\
\hline & 7.3 & 0.38 & n.d. & 1.1 & 2.0 & 5.7 & 305 & n.d. & 15 & 33 & 23 & 126 & n.d. & -17.1 & -1.2 & -2.2 \\
\hline & 9.0 & 0.42 & n.d. & 1.0 & 1.0 & 4.8 & 312 & n.d. & 15 & 38 & 24 & 131 & n.d. & -18.4 & -1.4 & -4.2 \\
\hline & 10 & 0.34 & n.d. & 0.96 & 0.87 & 4.6 & 316 & n.d. & 15 & 41 & 23 & 134 & n.d. & -19.3 & -1.4 & -5.3 \\
\hline & 12 & 0.42 & 0.06 & 0.93 & 1.7 & 4.5 & 328 & n.d. & 15 & 34 & 24 & 141 & n.d. & -19.6 & -1.4 & -6.1 \\
\hline & 11 & 0.37 & 0.18 & 1.0 & 0.97 & 4.8 & 323 & n.d. & 17 & 44 & 24 & 141 & n.d. & -20.4 & -1.5 & -5.5 \\
\hline & 11 & 0.54 & n.d. & 1.0 & 2.5 & 4.3 & 321 & n.d. & 17 & 46 & 24 & 141 & n.d. & -19.9 & -1.5 & -6.4 \\
\hline Cerro Afate & 105 & n.a. & $<1$ & $<1$ & 66 & 1800 & 22 & n.d. & n.a. & 109 & n.a. & n.a. & $<1$ & -51.0 & -6.6 & n.a. \\
\hline
\end{tabular}




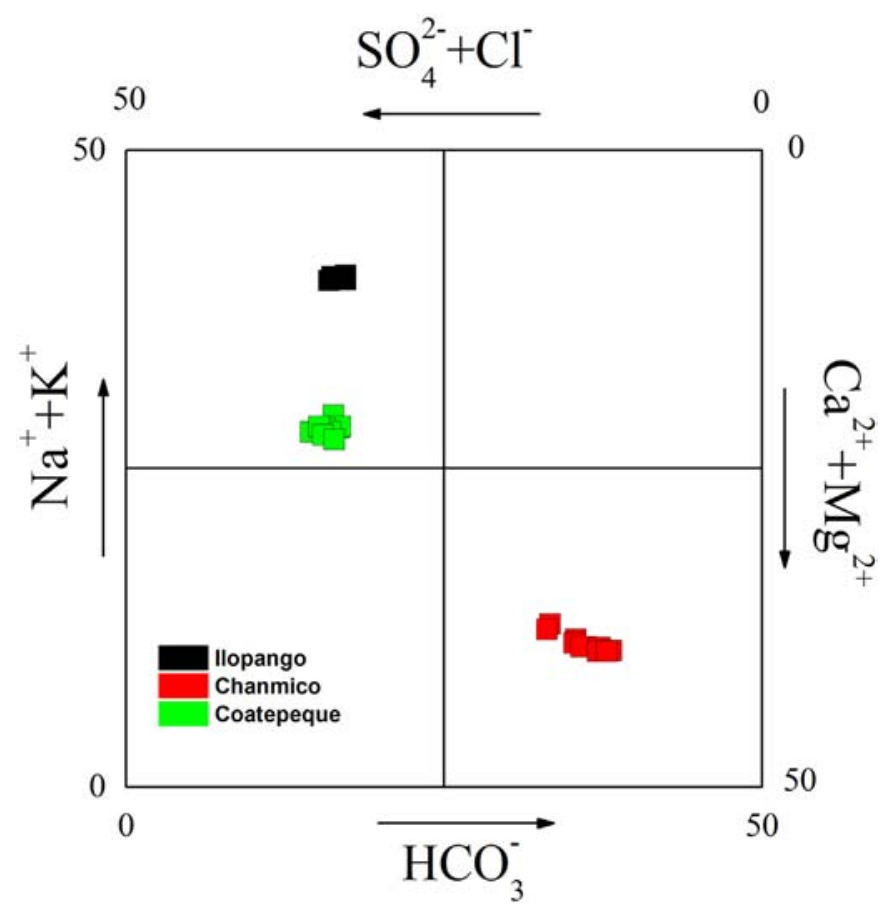

Fig. 3. Classification diagram of Langelier and Ludwig (1942).

the caldera, the last of which (6th century CE) partly devastated the local Mayan civilization (Mann et al., 2004 and references therein) and was probably also responsible for the extreme short-term climate cooling occurred 535-536 CE (Dull et al., 2010). The recent volcanic activity within the lake (1879 and 1880) formed the dome of Islas Quemadas (Richer et al., 2004). Saxby et al. (2016) suggested that magma is presently stored at about $6 \mathrm{~km}$ below the caldera. Lake Ilopango has estimated area and volume of $70.6 \mathrm{~km}^{2}$ and $9.97 \mathrm{~km}^{3}$, respectively, a perimeter of $52.5 \mathrm{~km}$ and steep sides sloping to a maximum depth of $240 \mathrm{~m}$ (SNET, 2000; Lopez et al., 2004; Esquivel, 2016). The Chaguite River to the west and the Desagüe River to the east are the main tributary and emissary, respectively (Lopez et al., 2004).

Lake Chanmico (Fig. 1e) occupies the crater bottom of a monogenetic volcano on the northwest side of the San Salvador Volcano, which generated phreatomagmatic events in recent times (400 BCE250 CE) (Sofield, 1998; Ferrés et al., 2011), as testified by the presence of surge, fall, and debris-flow deposits. The lake has an almost circular shape $\left(0.78 \mathrm{~km}^{2}\right)$ and a diameter of $\sim 1 \mathrm{~km}$.

\section{Materials and methods}

\subsection{Water and dissolved gas sampling}

Water and dissolved gas samples were collected in November 2016 along a vertical profile from the lake surface to the maximum depth, at regular depth intervals of $5 \mathrm{~m}$. A small diameter $(6 \mathrm{~mm})$ Rilsan@ tube, lowered at the sampling depth and connected to a $100 \mathrm{~mL}$ syringe equipped with a three-way teflon valve, was used to pump up the water (single hose method; Tassi and Rouwet, 2014). One water sample from the Cerro Afate (16 P 222396 1531972) mineral spring located near Lake Coatepeque (Fig. 1c) was also collected. Two non-filtered and two filtered $(0.45 \mu \mathrm{m})$ and acidified (with ultrapure $\mathrm{HCl}$ and $\mathrm{HNO}_{3}$, respectively) water samples were collected in polyethylene bottles for the analysis of anions, water isotopes ( $\delta \mathrm{D}-\mathrm{H}_{2} \mathrm{O}$ and $\delta{ }^{18} \mathrm{O}-\mathrm{H}_{2} \mathrm{O}$ ) and cations and trace species, respectively, after the displacement of a water volume at least twice the inner volume of the tube.
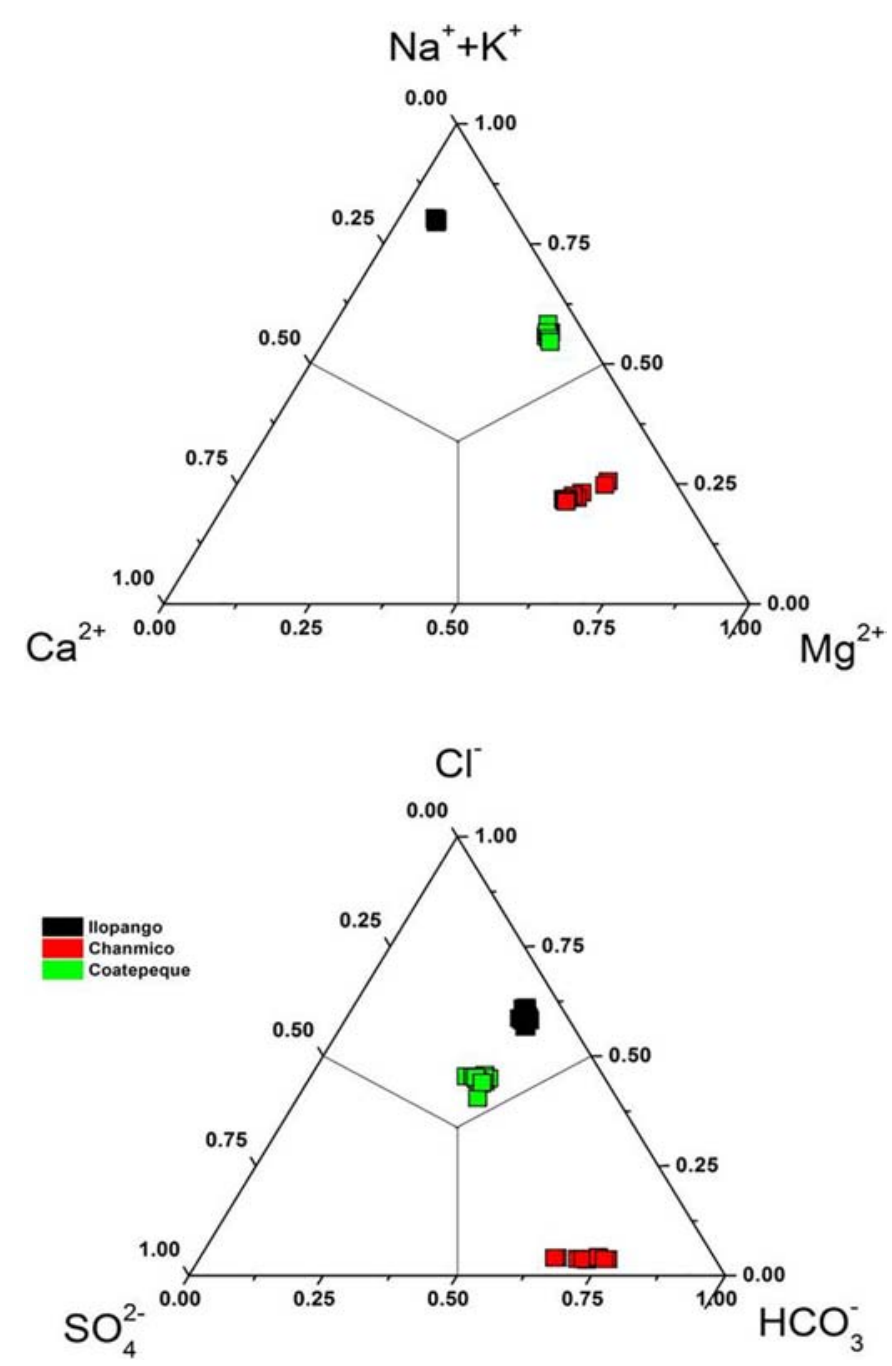

Fig. 4. Cation (up) and anion (down) triangular diagrams.

The isotope analyses of total dissolved inorganic carbon $\left(\delta^{13} \mathrm{C}\right.$-TDIC) were carried out on samples collected in $12 \mathrm{~mL}$ glass bottles with the addition of a few $\mathrm{mL}$ of anhydrous $\mathrm{H}_{3} \mathrm{PO}_{4}$ to prevent any fractionation process of carbon isotopes due to the presence of bacterial activity. Dissolved gases were collected using pre-evacuated $250 \mathrm{~mL}$ glass vials equipped with a Teflon stopcock. Once the vial was connected to the Rilsan@ tube through the three-way valve, the stopcock was opened to allow water entering up to about three fourths of the vial inner volume (Tassi et al., 2008, 2009).

\subsection{Field measurements}

Lake water temperature, dissolved $\mathrm{O}_{2}$, electrical conductivity (EC, temperature compensated) and $\mathrm{pH}$ were measured using a multiparametric probe (Idromarambiente SCRL IP-188A) equipped with a data logger for data storage. The probe (data acquisition frequency of $5 \mathrm{~s}$ ) was very slowly lowered from the surface to the maximum lake depth to obtain a measurement interval each $15 \mathrm{~cm}$. The nominal precisions were, as follows: depth $\pm 0.05 \mathrm{~m}$; temperature $\pm 0.03{ }^{\circ} \mathrm{C} ; \mathrm{O}_{2} \pm$ $1.56 \mu \mathrm{mol} / \mathrm{L} ; \mathrm{EC} \pm 0.01 \mathrm{mS} / \mathrm{cm}$ and $\mathrm{pH} \pm 0.1$.

\subsection{Chemical and isotopic analysis}

\subsubsection{Lake waters}

Alkalinity was measured by acidimetric titration (AC) with $0.01 \mathrm{~N}$ $\mathrm{HCl}$ using a Metrohm 794 automatic titration unit. The analytical error 


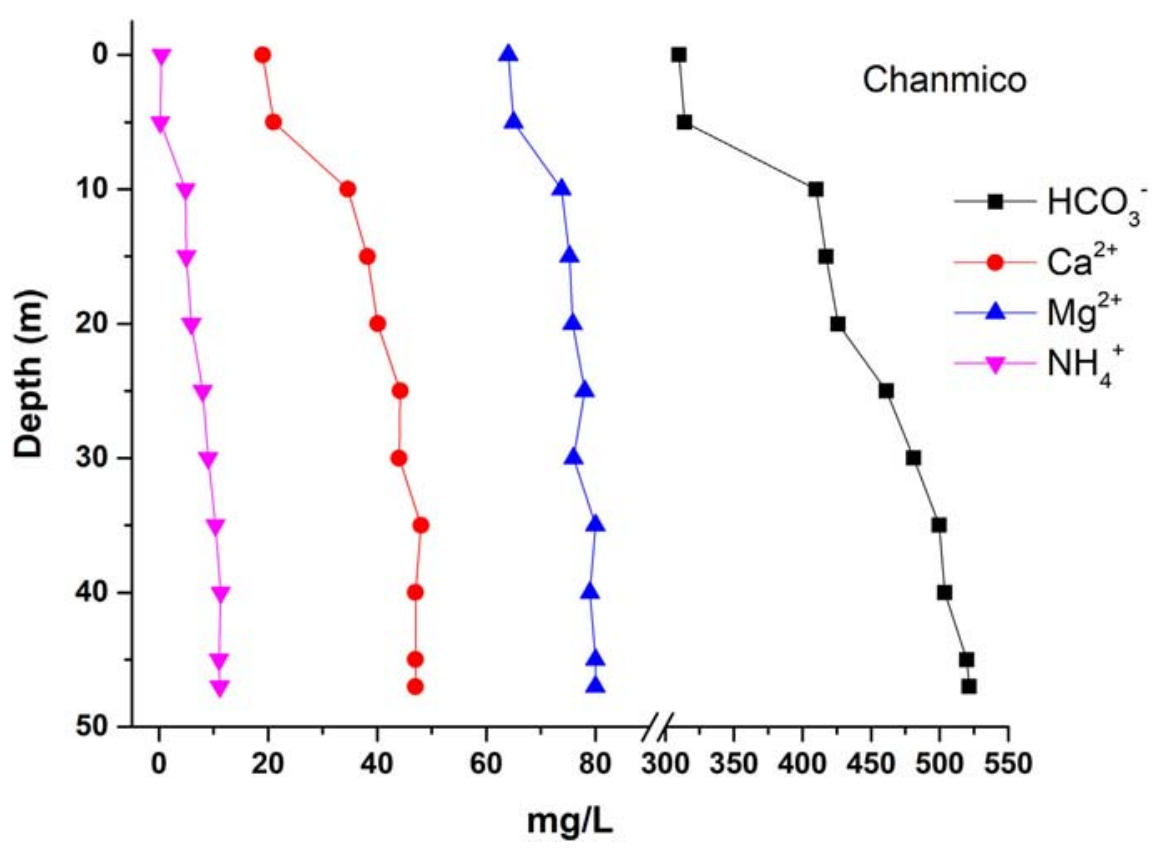

Fig. 5. Vertical distribution of $\mathrm{HCO}_{3}^{-}, \mathrm{Ca}^{2+}, \mathrm{Mg}^{2+}$ and $\mathrm{NH}_{4}^{+}$(in $\mathrm{mg} / \mathrm{L}$ ) for the Lake Chanmico.

for $\mathrm{AC}$ analysis was $\leq 5 \%$. The main anions $\left(\mathrm{Cl}^{-}, \mathrm{SO}_{4}^{2-}, \mathrm{NO}_{3}^{-}, \mathrm{Br}^{-}\right.$, and $\left.\mathrm{F}^{-}\right)$ and cations $\left(\mathrm{Na}^{+}, \mathrm{K}^{+}, \mathrm{Ca}^{2+}, \mathrm{Mg}^{2+}\right.$, and $\left.\mathrm{NH}_{4}^{+}\right)$were analyzed by ion chromatography (IC) using Metrohm 761 and Metrohm 861 chromatographs, respectively. Trace elements (As, B, Ba, Cd, Co, Cu, Fe $\mathrm{tot}_{\text {, }} \mathrm{Li}, \mathrm{Mn}$, $\mathrm{Ni}, \mathrm{Pb}, \mathrm{Sb}, \mathrm{Si}, \mathrm{Sr}$ and $\mathrm{Zn}$ ) were measured by inductively coupled plasma optical emission spectrometry (ICP-OES) using a Perkin Elmer Optima

Table 2

Concentrations of dissolved gases (in $\mu \mathrm{mol} / \mathrm{L}$ ) and carbon isotopes in $\mathrm{CO}_{2}$ along the vertical profiles of the Coatepeque, Ilopango and Chanmico lakes. n.d.: not detected.

\begin{tabular}{|c|c|c|c|c|c|c|c|c|c|}
\hline$\mu \mathrm{mol} / \mathrm{L}$ & $\begin{array}{l}\text { Depth } \\
\text { (m) }\end{array}$ & $\mathrm{CO}_{2}$ & $\mathrm{~N}_{2}$ & $\mathrm{Ar}$ & $\mathrm{CH}_{4}$ & $\mathrm{H}_{2}$ & $\mathrm{He}$ & $\begin{array}{l}\text { Gas } \\
\text { Total }\end{array}$ & $\delta^{13} \mathrm{C}-\mathrm{CO}_{2}$ \\
\hline \multirow[t]{11}{*}{ Coatepeque } & 5 & 1.2 & 491 & 11.7 & n.d. & n.d. & 0.011 & 504 & n.d. \\
\hline & 10 & 1.1 & 511 & 12.2 & n.d. & n.d. & 0.003 & 524 & -9.0 \\
\hline & 15 & 1.3 & 505 & 11.9 & n.d. & n.d. & 0.002 & 518 & n.d. \\
\hline & 20 & 1.5 & 495 & 11.8 & n.d. & n.d. & 0.003 & 508 & n.d. \\
\hline & 25 & 5.9 & 506 & 11.9 & n.d. & n.d. & 0.002 & 524 & n.d. \\
\hline & 30 & 51 & 505 & 11.6 & n.d. & n.d. & 0.005 & 568 & -6.0 \\
\hline & 40 & 58 & 501 & 11.5 & 0.21 & n.d. & 0.006 & 571 & n.d. \\
\hline & 60 & 115 & 498 & 11.7 & 2.3 & 0.2 & 0.012 & 627 & -8.2 \\
\hline & 80 & 107 & 508 & 11.3 & 5.4 & 0.8 & 0.015 & 633 & n.d. \\
\hline & 100 & 308 & 505 & 11.2 & 8.5 & 1.3 & 0.014 & 834 & -8.8 \\
\hline & 110 & 411 & 515 & 11 & 12 & 1.5 & 0.021 & 951 & -8.3 \\
\hline \multirow[t]{12}{*}{ Ilopango } & 5 & 1.1 & 455 & 11.9 & n.d. & n.d. & 0.003 & 468 & n.d. \\
\hline & 10 & 1.2 & 463 & 12.2 & n.d. & n.d. & 0.003 & 476 & n.d. \\
\hline & 15 & 1.2 & 469 & 12.3 & n.d. & n.d. & 0.002 & 483 & n.d. \\
\hline & 20 & 2.8 & 471 & 12.2 & n.d. & n.d. & 0.004 & 486 & n.d. \\
\hline & 25 & 3.9 & 477 & 12.1 & 0.05 & n.d. & 0.003 & 493 & n.d. \\
\hline & 30 & 8.1 & 468 & 11.9 & 0.11 & 0.1 & 0.004 & 488 & -7.7 \\
\hline & 40 & 12 & 466 & 12 & 0.09 & 0.3 & 0.003 & 490 & n.d. \\
\hline & 70 & 13 & 451 & 11.8 & 0.13 & 0.2 & 0.005 & 476 & -8.7 \\
\hline & 100 & 16 & 482 & 11.5 & 3.6 & 0.5 & 0.004 & 514 & -8.2 \\
\hline & 140 & 23 & 481 & 11.6 & 4.4 & 0.9 & 0.006 & 521 & -9.1 \\
\hline & 180 & 41 & 485 & 11.4 & 4.6 & 0.8 & 0.005 & 543 & -6.5 \\
\hline & 220 & 52 & 493 & 11.3 & 5.9 & 1.1 & 0.007 & 563 & -8.2 \\
\hline \multirow[t]{10}{*}{ Chanmico } & 5 & 2.1 & 492 & 12.3 & 3.9 & 0.2 & 0.002 & 511 & n.d. \\
\hline & 10 & 3.6 & 495 & 12.2 & 16 & 0.5 & 0.002 & 527 & -9.9 \\
\hline & 15 & 4.5 & 475 & 12.4 & 118 & 0.6 & 0.003 & 611 & n.d. \\
\hline & 20 & 5.6 & 483 & 12.1 & 215 & 1.1 & 0.002 & 717 & -11.7 \\
\hline & 25 & 24 & 490 & 12.2 & 231 & 1.6 & 0.003 & 759 & -11.9 \\
\hline & 30 & 55 & 485 & 12.1 & 233 & 2.2 & 0.004 & 787 & -11.6 \\
\hline & 35 & 181 & 491 & 12 & 344 & 2.1 & 0.005 & 1030 & -11.6 \\
\hline & 40 & 213 & 489 & 11.8 & 455 & 2.5 & 0.004 & 1171 & -12.4 \\
\hline & 45 & 239 & 485 & 11.7 & 467 & 2.6 & 0.006 & 1205 & -11.1 \\
\hline & 47 & 208 & 483 & 11.6 & 481 & 2.9 & 0.008 & 1187 & -11.5 \\
\hline
\end{tabular}

8000. The analytical error for IC and ICP-OES analysis were $<5 \%$ and $<10 \%$, respectively.

The ${ }^{18} \mathrm{O} /{ }^{16} \mathrm{O}$ and ${ }^{2} \mathrm{H} /{ }^{1} \mathrm{H}$ ratios of water (expressed as $\delta^{18} \mathrm{O}-\mathrm{H}_{2} \mathrm{O}$ and $\delta \mathrm{D}-\mathrm{H}_{2} \mathrm{O} \%$ vs. V-SMOW) were determined by isotope ratio mass spectrometry (IRMS). Oxygen isotopes measurements were carried out by using a Gas Bench peripheral coupled with a Thermo Delta V mass spectrometer. A TC-EA peripheral interfaced by means of a ConFloIV with Thermo Delta XP mass spectrometer was used for hydrogen isotopes. The analytical error for IRMS was $\pm 0.1 \%$ for $\delta^{18} \mathrm{O}$ and better than \pm $1 \%$ for $\delta \mathrm{D}$.

The ${ }^{13} \mathrm{C} /{ }^{12} \mathrm{C}$ of Total Dissolved Inorganic Carbon (TDIC), expressed as $\delta^{13} \mathrm{C}$-TDIC \% vs. V-PDB, were analyzed at INGV-Palermo laboratories with a CF-IRMS technique, following the procedure described by Salata et al. (2000). $\delta^{13} \mathrm{C}$-TDIC measurements were carried out by using a Finnigas Delta Plus XP equipped with a Thermo TRACE CG. A detailed description of the analytical system can be found in Grassa et al. (2010). The analytical precision was better than $0.1 \%$.

\subsubsection{Dissolved gases}

The chemical composition of the inorganic dissolved gases in the headspace of the sampling flasks $\left(\mathrm{CO}_{2}, \mathrm{~N}_{2}, \mathrm{Ar}, \mathrm{H}_{2}\right.$ and $\left.\mathrm{He}\right)$ was determined by gas chromatography (GC) using a Shimadzu 15A equipped with a $5 \mathrm{~m}$ long stainless steel column packed with Porapak 80/ 100 mesh and a Thermal Conductivity Detector (TCD), whereas $\mathrm{CH}_{4}$ was analyzed using a Shimadzu $14 \mathrm{~A}$ equipped with a $10 \mathrm{~m}$ long stainless steel column packed with Chromosorb PAW 80/100 mesh coated with 23\% SP 1700 and a Flame Ionization Detector (FID) (Vaselli et al., 2006). The analytical error for GC analysis was $\leq 5 \%$. The number of moles of each gas species in the liquid $\left(n_{i, 1}\right)$ was calculated on the basis of those in the flask headspace $\left(n_{i, g}\right)$ by means of the Henry's law constants and assuming that in the sampling flasks the separated gas phase was in equilibrium with the liquid (Wilhelm et al., 1977). The total moles of each gas species in the water sample was given by the sum of $n_{i, 1}$ and $n_{i, g}$.

The isotopic composition of dissolved $\mathrm{CO}_{2}\left(\delta^{13} \mathrm{C}_{-} \mathrm{CO}_{2}\right.$ expressed as \%。 vs. V-PDB) was determined by analyzing the ${ }^{13} \mathrm{C} /{ }^{12} \mathrm{C}$ values of $\mathrm{CO}_{2}$ in the sampling flask headspace $\left(\delta^{13} \mathrm{C}-\mathrm{CO}_{2}\right.$ meas $)$ using a Finnigan Delta $\mathrm{S}$ mass spectrometer, after a two-step extraction and purification procedures of the gas mixtures by using liquid $\mathrm{N}_{2}$ and a solid-liquid mixture of liquid $\mathrm{N}_{2}$ and trichloroethylene (Evans et al., 1998; Vaselli et al., 2006). 


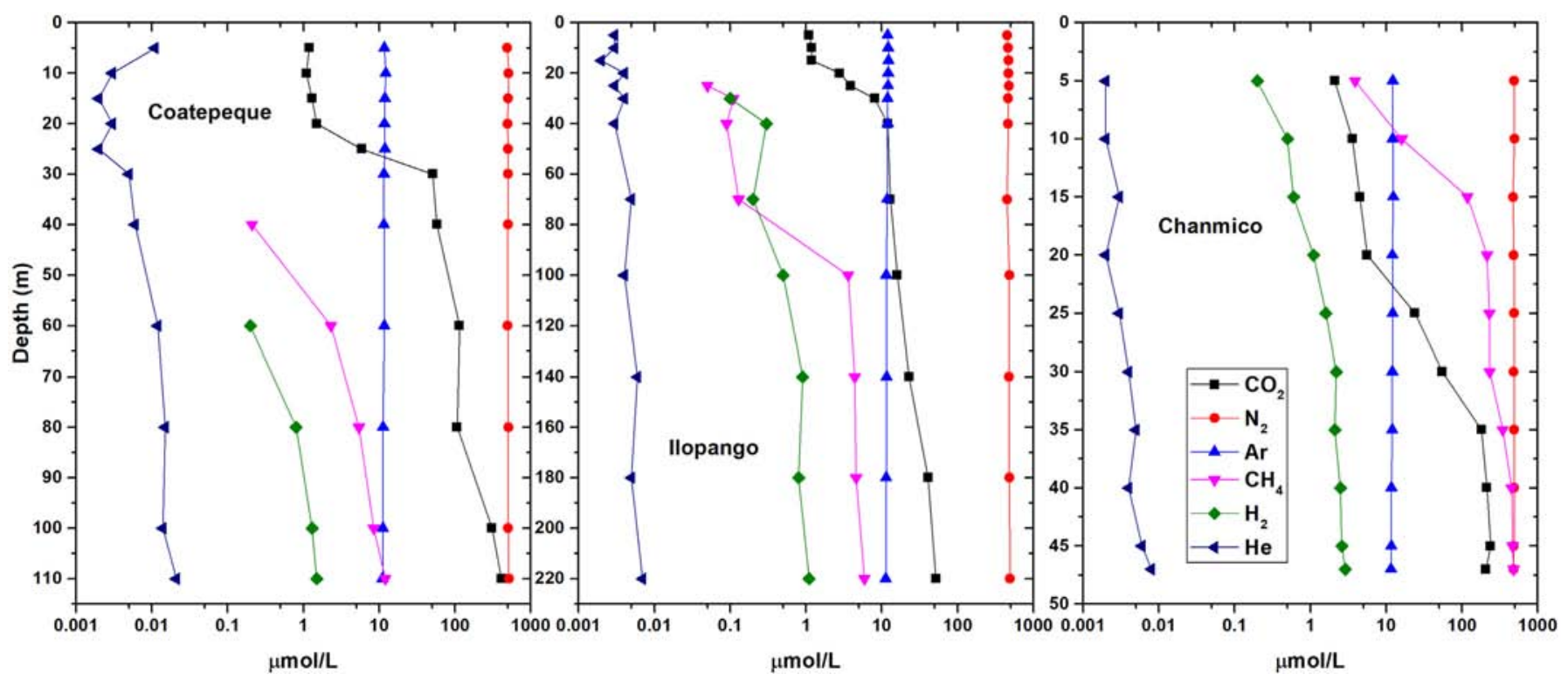

Fig. 6. Concentrations (in $\mu \mathrm{mol} / \mathrm{L}$ ) of $\mathrm{CO}_{2}, \mathrm{~N}_{2}, \mathrm{Ar}, \mathrm{CH}_{4}, \mathrm{H}_{2}$ ad He along the vertical profiles for the Coatepeque, Ilopango and Chanmico lakes.

Internal (Carrara and San Vincenzo marbles) and international (NBS18 and NBS19) standards were used to estimate accuracy. The analytical error and the reproducibility were $\pm 0.05 \%$ ond $\pm 0.1 \%$, respectively. The $\delta^{13} \mathrm{C}$ values of dissolved $\mathrm{CO}_{2}$ were then calculated from the measured $\delta^{13} \mathrm{C}-\mathrm{CO}_{2 \text { meas }}$ on the basis of the enrichment factor $\left(\varepsilon_{1}\right)$ for gaswater isotope equilibrium proposed by Zhang et al. (1995), as follows:

$\varepsilon_{1}=\delta^{13} \mathrm{C}-\mathrm{CO}_{2}-\delta^{13} \mathrm{C}-\mathrm{CO}_{2 \text { meas }}=(0.0049 \times \mathrm{T})-1.31$

where temperature (T) is expressed in ${ }^{\circ} \mathrm{C}$.

\section{Results}

\subsection{Vertical profiles of water temperature, EC, $\mathrm{pH}$ and dissolved $\mathrm{O}_{2}$}

Temperature, $\mathrm{EC}, \mathrm{pH}$, and dissolved $\mathrm{O}_{2}$ concentrations along the vertical profiles of the five lakes are shown in Fig. 2. The Coatepeque,

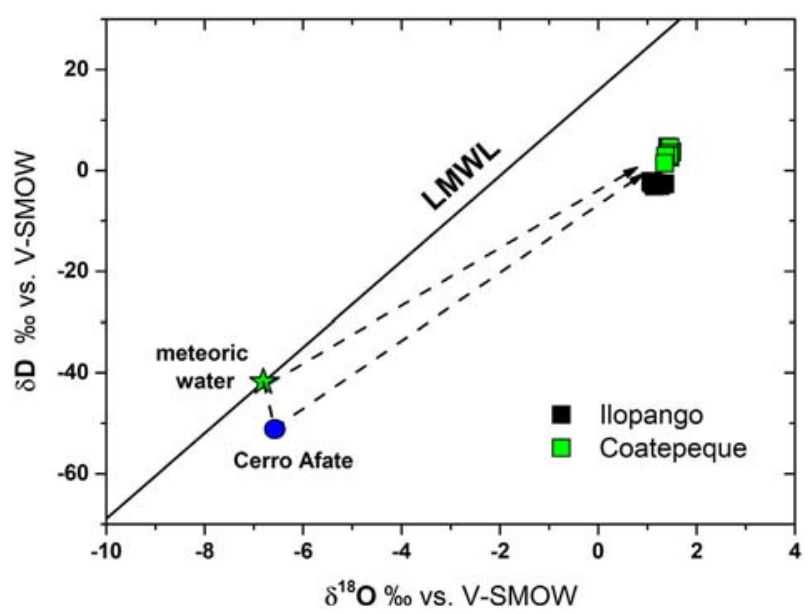

Fig. 7. $\delta \mathrm{D}$ vs. $\delta^{18} \mathrm{O}$ (in \% vs. V-SMOW) binary diagram of the Coatepeque (green) and Ilopango (black) lake waters. Green star: the isotopic composition of the local meteoric water (from IAEA/WMO, 2018, Coatepeque site); blue circle: isotopic composition of Cerro Afate hot spring; black line: the local meteoric water line (from IAEA/WMO, 2018, Coatepeque site). (For interpretation of the references to color in this figure legend, the reader is referred to the web version of this article.)
Ilopango and Chanmico volcanic lakes showed a thermocline at 30-40 m, 20-40 $\mathrm{m}$ and 5-15 $\mathrm{m}$ depth, respectively, separating the relatively warm shallow waters, where temperature ranged from 29 (Ilopango and Chanmico) to $25^{\circ} \mathrm{C}$ (Coatepeque), and the hypolimnetic waters, showing 26,25 and $23{ }^{\circ} \mathrm{C}$, respectively. At the thermoclines, slight conductivity increases (from 1540 to 1580 , from 1550 to 1600 and from 625 to $800 \mu \mathrm{S} / \mathrm{cm}$, respectively) and $\mathrm{pH}$ decreases (from 8.8 to 7.9 , from 8.6 to 7.6 and from 9 to 7.5 , respectively) were recorded. In the hypolimnion, the vertical profiles of temperature, $\mathrm{EC}$ and $\mathrm{pH}$ did not show substantial variations, excepting Lake Chanmico that showed a EC increase (up to $895 \mu \mathrm{S} / \mathrm{cm}$ ) and a gradual $\mathrm{pH}$ decrease (down to 7.3). Anaerobic waters were below 33, 24 and $4 \mathrm{~m}$ depth, at Coatepeque, Ilopango and Chanmico respectively, whilst above these depths dissolved $\mathrm{O}_{2}$ was up to $0.55,2.39$ and $1.27 \mathrm{mg} / \mathrm{L}$, respectively.

\subsection{Chemical and isotopic composition of the lake waters}

Chemical composition (main and trace solutes, in $\mathrm{mg} / \mathrm{L}$ ), total dissolved solids (TDS, in $\mathrm{mg} / \mathrm{L}$ ) and $\delta \mathrm{D}-\mathrm{H}_{2} \mathrm{O}, \delta^{18} \mathrm{O}-\mathrm{H}_{2} \mathrm{O}(\%$ V-SMOW) and $\delta^{13} \mathrm{C}$-TDIC (\% V-PDB) values of three lakes are listed in Table 1.

The Coatepeque and Ilopango waters were $\mathrm{Na}^{+}-\mathrm{Cl}^{-}\left(\mathrm{SO}_{4}^{2-}\right)$ and $\mathrm{Na}^{+}-\mathrm{Cl}^{-}\left(\mathrm{HCO}_{3}^{-}\right)\left(\mathrm{Na}^{+}\right.$up to 232 and $330 \mathrm{mg} / \mathrm{L}, \mathrm{Cl}^{-}$up to 294 and $375 \mathrm{mg} / \mathrm{L}, \mathrm{SO}_{4}^{2-}$ up to 224 and $76 \mathrm{mg} / \mathrm{L}, \mathrm{HCO}_{3}^{-}$up to 358 and $366 \mathrm{mg} / \mathrm{L}$, respectively), with TDS values up to 1226 and $1216 \mathrm{mg} / \mathrm{L}$, respectively, whereas those from Lake Chanmico showed a $\mathrm{Mg}^{2+}-\mathrm{HCO}_{3}^{-}$ composition and TDS values between 566 and $856 \mathrm{mg} / \mathrm{L}$ (Figs. 3-4). Cerro Afate mineral spring near Lake Coatepeque was $\mathrm{Na}^{+}-\mathrm{Cl}^{-}$, with a TDS value of $1560 \mathrm{mg} / \mathrm{L}$ (Table 1). At Chanmico, $\mathrm{HCO}_{3}^{-}, \mathrm{Ca}^{2+}, \mathrm{Mg}^{2+}$ and $\mathrm{NH}_{4}^{+}$concentrations increased with depth (up to 522, 48, 80 and $11 \mathrm{mg} / \mathrm{L}$, respectively; Fig. 5). Conversely, no substantial chemical variations were measured along the water columns of Coatepeque and Ilopango (Table 1). $\mathrm{F}^{-}, \mathrm{Br}^{-}, \mathrm{NO}_{3}^{-}$and $\mathrm{K}^{+}$abundances were up to 0.83 , $1.3,13$ and $44 \mathrm{mg} / \mathrm{L}$, respectively.

All the three lakes showed relatively high contents of B (up to $9.6 \mathrm{mg} / \mathrm{L}$ at Ilopango), $\mathrm{Si}$ (up to $24 \mathrm{mg} / \mathrm{L}$ at Chanmico) and $\mathrm{Sr}$ (up to $278 \mu \mathrm{g} / \mathrm{L}$ at Ilopango). Coatepeque and Ilopango were also characterized by relatively high concentrations of As (up to 104 and $648 \mu \mathrm{g} / \mathrm{L}$, respectively) and Li (up to 564 and $692 \mu \mathrm{g} / \mathrm{L}$, respectively), whilst those of Ba and Mn were up to 84 (Ilopango) and 328 (Chanmico) $\mu \mathrm{g} / \mathrm{L}$, respectively. The highest concentrations of $\mathrm{Pb}$ and $\mathrm{Sb}(27$ and $50 \mu \mathrm{g} / \mathrm{L}$, respectively) were measured at $20 \mathrm{~m}$ depth in the Lake Ilopango, whereas 

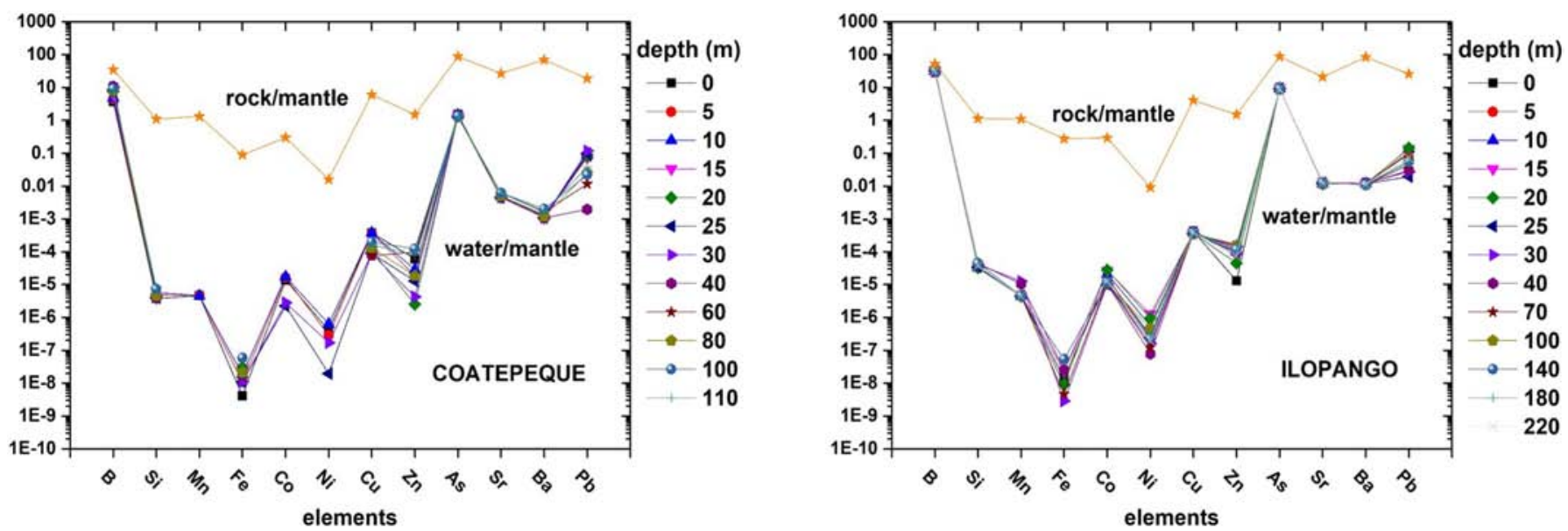

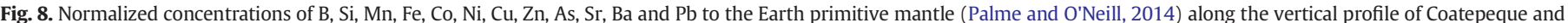

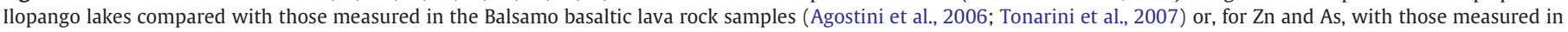
basement andesites (Rapprich and Hradecký, 2005).

those of other trace elements ( $\mathrm{Cd}, \mathrm{Co}, \mathrm{Cu}, \mathrm{Fe}, \mathrm{Ni}$ and $\mathrm{Zn}$ ) were $<10 \mu \mathrm{g} / \mathrm{L}$. Cerro Afate mineral spring showed high contents of As, B and Li (1243, 7740 and $1800 \mu \mathrm{g} / \mathrm{L}$, respectively; Table 1 ).

The $\delta \mathrm{D}-\mathrm{H}_{2} \mathrm{O}$ values of Coatepeque, Ilopango and Chanmico lakes varied from 1.4 to $4.7 \%$, from -3.1 to $-2.2 \%$ and from -20.4 to $-7.2 \%$ ovs. $\mathrm{V}-\mathrm{SMOW}$, respectively, whilst those of $\delta^{18} \mathrm{O}-\mathrm{H}_{2} \mathrm{O}$ ranged from 1.4 to $1.5 \%$, from 1.1 to $1.4 \%$ and from -1.5 to $0.5 \%$ o vs. V-SMOW, respectively. The $\delta \mathrm{D}-\mathrm{H}_{2} \mathrm{O}$ and $\delta{ }^{18} \mathrm{O}-\mathrm{H}_{2} \mathrm{O}$ values of Cerro Afate mineral spring were -51 and $-6.6 \%$ vs. V-SMOW, respectively. The $\delta^{13} \mathrm{C}$-TDIC values of Coatepeque, Ilopango and Chanmico lakes ranged from -1.3 to $1.5 \%$, from -1.9 to $3.6 \%$ and from -6.4 to $0.5 \%$ ovs. V-PDB, respectively.

\subsection{Chemical and isotopic composition of dissolved gases}

The chemical (in $\mu \mathrm{mol} / \mathrm{L}$ ) and isotopic $\left(\delta^{13} \mathrm{C}-\mathrm{CO}_{2}\right)$ composition of the dissolved gases $\left(\mathrm{CO}_{2}, \mathrm{~N}_{2}, \mathrm{Ar}, \mathrm{CH}_{4}, \mathrm{H}_{2}\right.$ and $\left.\mathrm{He}\right)$ and the total gas concentration (in $\mu \mathrm{mol} / \mathrm{L}$ ) are reported in Table 2.

Nitrogen was the most abundant dissolved gas in the three lakes (ranging from 451 to $515 \mu \mathrm{mol} / \mathrm{L}$ ) and did not vary significantly with depth. On the contrary, $\mathrm{CO}_{2}$ concentrations were increasing with

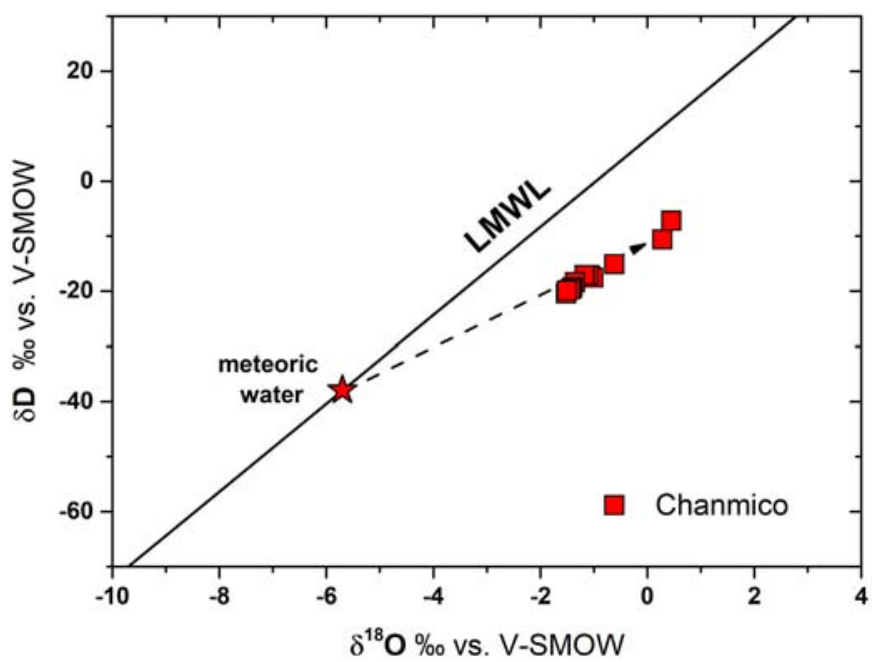

Fig. 9. $\delta \mathrm{D}$ vs. $\delta^{18} \mathrm{O}$ (in \% vs. V-SMOW) binary diagram of the Chanmico (red) lake waters. Red star: isotopic composition of the local meteoric water (from IAEA/WMO, 2018, San Andres site); black line: local meteoric water line (from IAEA/WMO, 2018, San Andres site). (For interpretation of the references to color in this figure legend, the reader is referred to the web version of this article.) depth, reaching the highest values at the lake bottoms $(411,52$ and $239 \mu \mathrm{mol} / \mathrm{L}$ at Coatepeque, Ilopango and Chanmico, respectively; Fig. 6). Deeper waters also showed increasing contents of $\mathrm{H}_{2}$ (up to $2.9 \mu \mathrm{mol} / \mathrm{L}$ at Lake Chanmico) and $\mathrm{CH}_{4}$. Argon and He contents (up to $12.4 \mu \mathrm{mol} / \mathrm{L}$ ) were almost constant along the vertical profile, excepting He at Lake Coatepeque that increased up to $0.021 \mu \mathrm{mol} / \mathrm{L}$. The total gas concentration at Coatepeque, Ilopango and Chanmico lakes was up to 951,563 and $1205 \mu \mathrm{mol} / \mathrm{L}$, respectively.

The $\delta^{13} \mathrm{C}-\mathrm{CO}_{2}$ values at Coatepeque, Ilopango and Chanmico ranged from -9.0 to $-6.0 \%$, from -9.1 to $-6.5 \%$ and from -12.4 to $-9.9 \%$ 。 vs. V-PDB, respectively, although no carbon isotope analyses were carried out on samples with very low dissolved $\mathrm{CO}_{2}$.

\section{Discussion}

\subsection{Processes controlling lakes water chemistry}

\subsubsection{Lake Coatepeque and Lake Ilopango}

Coatepeque and Ilopango lakes were characterized by a $\mathrm{Na}^{+}-\mathrm{Cl}^{-}$ composition, unlikely related to input of seawater, given that the two

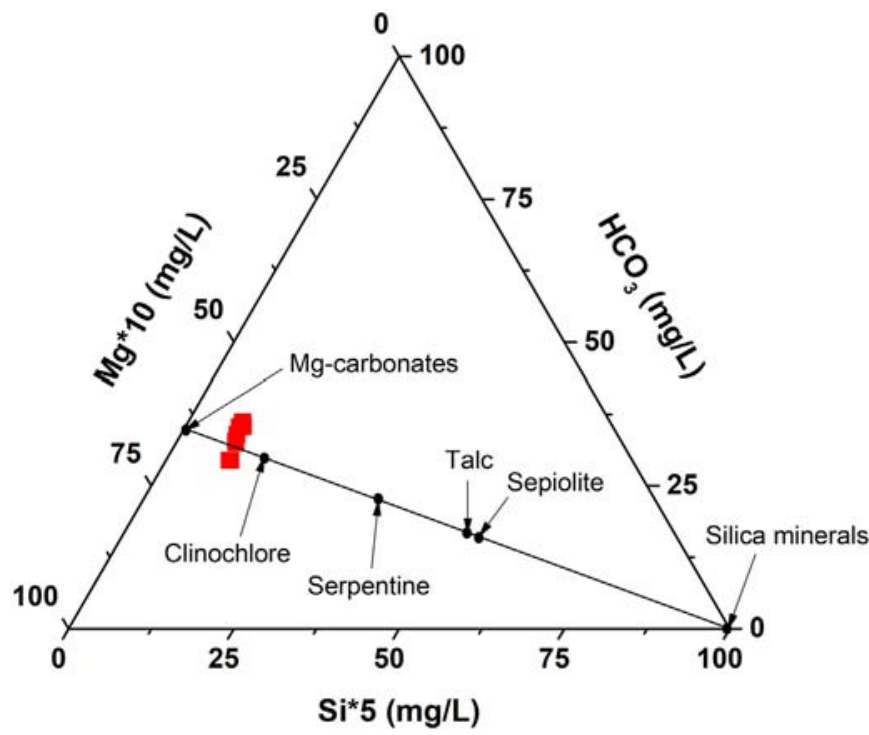

Fig. 10. $\mathrm{Si}^{*} 5-\mathrm{Mg}^{*} 10-\mathrm{HCO}_{3}$ triangular diagrams for the Chanmico lake waters. Black circles: expected compositions of the aqueous phase controlled by $\mathrm{CO}_{2}$-driven dissolution of $\mathrm{Mg}$ bearing solid phases (Fantoni et al., 2002). 
Table 3

Saturation indexes with depth of selected minerals for Lake Chanmico.

\begin{tabular}{|c|c|c|c|c|c|c|c|c|c|c|c|c|c|}
\hline & $\begin{array}{l}\text { Depth } \\
(\mathrm{m})\end{array}$ & si_Aragonite & si_Brucite & si_Calcite & si_Chrysotile & si_Diopside & si_Enstatite & si_Forsterite & si_Huntite & si_Magnesite & si_Quartz & si_Sepiolite & si_Talc \\
\hline \multirow[t]{11}{*}{ Chanmico } & 0 & 0.1664 & -2.8564 & 0.3118 & 2.7201 & -1.2426 & -1.0604 & -4.129 & 0.6996 & 0.645 & 0.8178 & 4.0262 & 6.3353 \\
\hline & 5 & 0.2016 & -2.8981 & 0.347 & 2.6299 & -1.2651 & -1.0965 & -4.2115 & 0.7026 & 0.6358 & 0.8252 & 3.9404 & 6.2614 \\
\hline & 10 & 0.4457 & -3.0633 & 0.5912 & 2.3918 & -1.2165 & -1.1722 & -4.4679 & 1.1172 & 0.6979 & 0.9208 & 3.9736 & 6.2192 \\
\hline & 15 & 0.4853 & -3.0912 & 0.6308 & 2.3636 & -1.1918 & -1.181 & -4.5079 & 1.1569 & 0.6991 & 0.9412 & 4.0109 & 6.2328 \\
\hline & 20 & 0.5048 & -3.1091 & 0.6503 & 2.2958 & -1.2237 & -1.2076 & -4.5532 & 1.1725 & 0.698 & 0.9327 & 3.8939 & 6.1484 \\
\hline & 25 & 0.5411 & -3.1706 & 0.6866 & 2.1124 & -1.316 & -1.2686 & -4.6756 & 1.2288 & 0.7047 & 0.9332 & 3.6508 & 5.9659 \\
\hline & 30 & 0.5226 & -3.2558 & 0.6681 & 1.8989 & -1.4366 & -1.3327 & -4.825 & 1.1319 & 0.6785 & 0.9543 & 3.4366 & 5.7946 \\
\hline & 35 & 0.4266 & -3.5377 & 0.5721 & 1.0252 & -2.0115 & -1.6287 & -5.4028 & 0.6969 & 0.5656 & 0.9403 & 2.2247 & 4.8928 \\
\hline & 40 & 0.3929 & -3.6039 & 0.5384 & 0.8477 & -2.1273 & -1.6843 & -5.5246 & 0.5759 & 0.5364 & 0.9508 & 2.0233 & 4.7365 \\
\hline & 45 & 0.3836 & -3.6408 & 0.5291 & 0.7372 & -2.2045 & -1.7211 & -5.5983 & 0.5495 & 0.5307 & 0.951 & 1.8764 & 4.6262 \\
\hline & 47 & 0.4167 & -3.5762 & 0.5622 & 0.9409 & -2.0668 & -1.6516 & -5.4642 & 0.6859 & 0.5652 & 0.9558 & 2.1642 & 4.8396 \\
\hline
\end{tabular}

lakes are located at about 50 and $30 \mathrm{~km}$, respectively, from the Pacific coast. The most reliable explanation for this peculiar chemistry implies the input of deep-seated fluids. In fact, these waters showed features typical of hydrothermal fluids, as follows: i) relatively high TDS values; ii) $\mathrm{Cl}^{-} / \mathrm{Br}^{-}$molar ratios in the range of geothermal brines $(\leq 650)$ (Fontes and Matray, 1993; Davis et al., 2001; Risacher et al., 2011); iii) high As, B and Li concentrations (Table 1) (e.g. Brondi et al., 1973; Aggarwal et al., 2000 and references therein; Webster and Nordstrom, 2003; Aiuppa et al., 2006; Göb et al., 2013; Cinti et al., 2015, 2017); iv) relatively high $\mathrm{Si}$ content; v) $\mathrm{Cl}^{-} / \mathrm{SO}_{4}^{2-}$ ratio $>1$. Anomalously high $\mathrm{As}$ and $\mathrm{B}$ concentrations, i.e. higher than the drinking water standard for As $(0.01 \mathrm{mg} / \mathrm{L}$; US EPA, 2001) and guideline for B $(0.5 \mathrm{mg} / \mathrm{L}$; WHO, 2003), were already reported by other studies carried out at Lake Ilopango (Ransom, 2002; Lopez et al., 2009, 2012). Accordingly, based on gravimetric and seismic data and diffuse $\mathrm{CO}_{2}$ flux and radon concentrations, Lopez et al. $(2004,2012)$ and Saxby et al. (2016) suggested the occurrence of a hydrothermal system at a depth of few $\mathrm{km}$ beneath the southern part of Lake Ilopango. Input of hydrothermal fluids into Lake Ilopango is also supported by the occasional observation of floating sulfur nodules at the lake surface during occasional roll-over episodes (Lopez et al., 2004; Varekamp, 2015) and the occurrence of hot water springs near the Island of Cerro Los Patos (Lopez et al., 2009).

The $\delta \mathrm{D}-\mathrm{H}_{2} \mathrm{O}$ vs. $\delta^{18} \mathrm{O}-\mathrm{H}_{2} \mathrm{O}$ diagram (Fig. 7), a useful tool to investigate potential water sources feeding the lakes (Varekamp and Kreulen, 2000 and references therein), also reporting the local meteoric water line (from IAEA/WMO, 2018, Coatepeque site), shows that Coatepeque and Ilopango waters are enriched in ${ }^{2} \mathrm{H}$ and ${ }^{18} \mathrm{O}$ with respect to the mean

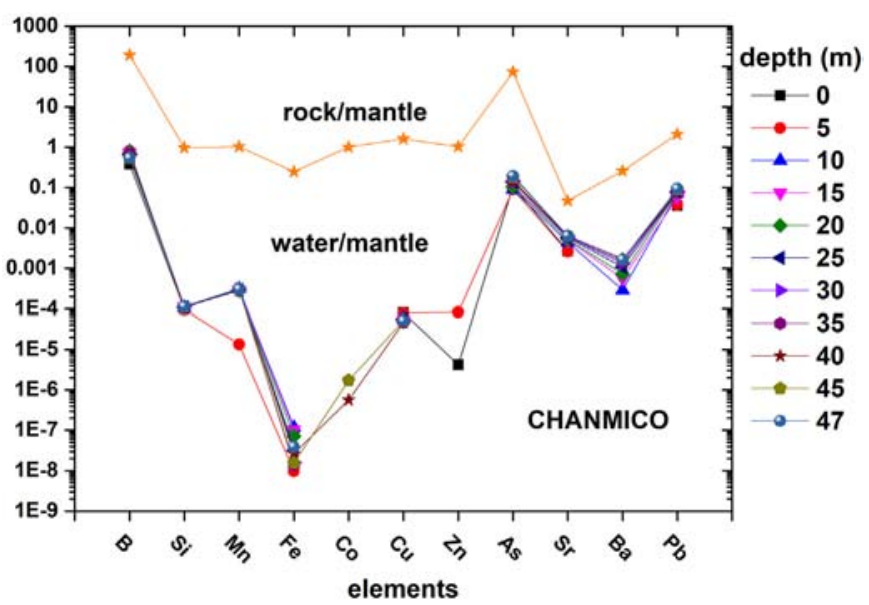

Fig. 11. Normalized concentrations of $\mathrm{B}, \mathrm{Si}, \mathrm{Mn}, \mathrm{Fe}, \mathrm{Co}, \mathrm{Ni}, \mathrm{Cu}, \mathrm{Zn}, \mathrm{As}, \mathrm{Sr}$, $\mathrm{Ba}$ and $\mathrm{Pb}$ to the Earth primitive mantle (Palme and O'Neill, 2014) along the vertical profile of Lake Chanmico normalized to those of Earth's mantle (Palme and O'Neill, 2014) and compared with those measured in a serpentinized peridotite (Schwarzenbach et al., 2014) belonging to the Santa Elena Ophiolite (Costa Rica). B and As were normalized to serpentinitic rock composition from Boström and Valdes (1969), Bonatti et al. (1984) and Martin et al. (2016). local meteoric water (from IAEA/WMO, 2018, Coatepeque site). For both lakes, this may depend on evaporation processes of (i) the lakefeeding meteoric water, (ii) a mature hydrothermal component deriving from prolonged water-rock interactions, like the Cerro Afate hot spring entering Lake Coatepeque or (iii) both the two processes (Fig. 7). According to these hypotheses, in order to verify whether the observed chemistry was due to a mixture between meteoric and more saline (hydrothermal) waters, a chemical two-component (meteoric and hydrothermal) mixing model was developed by using the geochemical code PHREEQC 3.3.7.11094 (llnl.dat database; Parkhurst and Appelo, 1999). The simulation included the Cerro Afate spring, assumed as the hydrothermal endmember, and a generic low-salinity water, assumed as the meteoric endmember since, to the best of our knowledge, no chemical data of local rainwater are available. Focusing on the main anion $\left(\mathrm{Cl}^{-}\right)$, which can be considered a useful geochemical tracer, the result of the simulation shows that the water composition of Lake Coatepeque can be reproduced by mixing the meteoric and hydrothermal end-members by $45 \%-55 \%$, respectively. Such a high hydrothermal fluid contribution for Coatepeque is also supported by literature, reporting the presence of gas emissions nearby Cerro Pacho, as well as a number of hot springs discharging at the lake shores (Salazar et al., 2004; FORGAES and SNET, 2006; Lopez et al., 2012; Rodriguez et al., 2014). When considering the same meteoric and hydrothermal endmembers of Lake Coatepeque, the $\mathrm{Cl}^{-}$simulation indicates that a 30\%-70\% mixing may reproduce the water composition of Lake Ilopango. The relatively high $\mathrm{SO}_{4}^{2-}$ concentrations (Table 1 ) of Lake Coatepeque can possibly be ascribed to dissolution of $\mathrm{H}_{2} \mathrm{~S}$ (e.g. Lopez et al., 2012; Tassi et al., 2018a) from the volcanic-hydrothermal system of the nearby Santa Ana volcano. The relatively high concentrations of $\mathrm{HCO}_{3}^{-}$in both Coatepeque and Ilopango lakes are likely controlled by

Table 4

$\mathrm{CO}_{2}$ and $\mathrm{CH}_{4}$ concentrations (in $\mathrm{mmol} / \mathrm{L}$ ) at the bottom of Coatepeque, Ilopango and Chanmico lakes compared to those measured at Lake Kivu (Tassi et al., 2009), Costa Rican and Italian volcanic lakes (Cabassi et al., 2013, 2014) and Lake Pavin (Zimmer et al., 2015). n.a.: not analyzed.

\begin{tabular}{|c|c|c|c|c|}
\hline $\begin{array}{l}\text { Lakes } \\
\text { (bottom) }\end{array}$ & $\begin{array}{l}\text { Depth } \\
(\mathrm{m})\end{array}$ & $\begin{array}{l}\mathrm{CO}_{2} \\
(\mathrm{mmol} / \mathrm{L})\end{array}$ & $\begin{array}{l}\mathrm{CH}_{4} \\
(\mathrm{mmol} / \mathrm{L})\end{array}$ & \\
\hline Coatepeque & 110 & 0.4 & 0.012 & El Salvador volcanic lakes this \\
\hline Ilopango & 220 & 0.052 & 0.0059 & work \\
\hline Chanmico & 47 & 0.21 & 0.48 & \\
\hline Kivu (DRC) & 470 & 137 & 17 & Tassi et al., 2009 \\
\hline $\begin{array}{l}\text { Monticchio } \\
\text { Grande }\end{array}$ & 35 & 4.9 & 0.39 & $\begin{array}{l}\text { Italy volcanic lakes Cabassi et al., } \\
2013\end{array}$ \\
\hline $\begin{array}{l}\text { Monticchio } \\
\text { Piccolo }\end{array}$ & 38 & 14 & 5 & \\
\hline Averno & 33 & 5.2 & 1.1 & \\
\hline Albano & 167 & 1.9 & 0.4 & \\
\hline Hule & 21 & 1.1 & 0.23 & Costa Rica volcanic lakes Cabassi \\
\hline Rio Cuarto & 67 & 1.8 & 2.8 & et al., 2014 \\
\hline $\begin{array}{l}\text { Pavin } \\
\quad \text { (France) }\end{array}$ & 90 & 9.6 & n.a. & Zimmer et al., 2015 \\
\hline
\end{tabular}



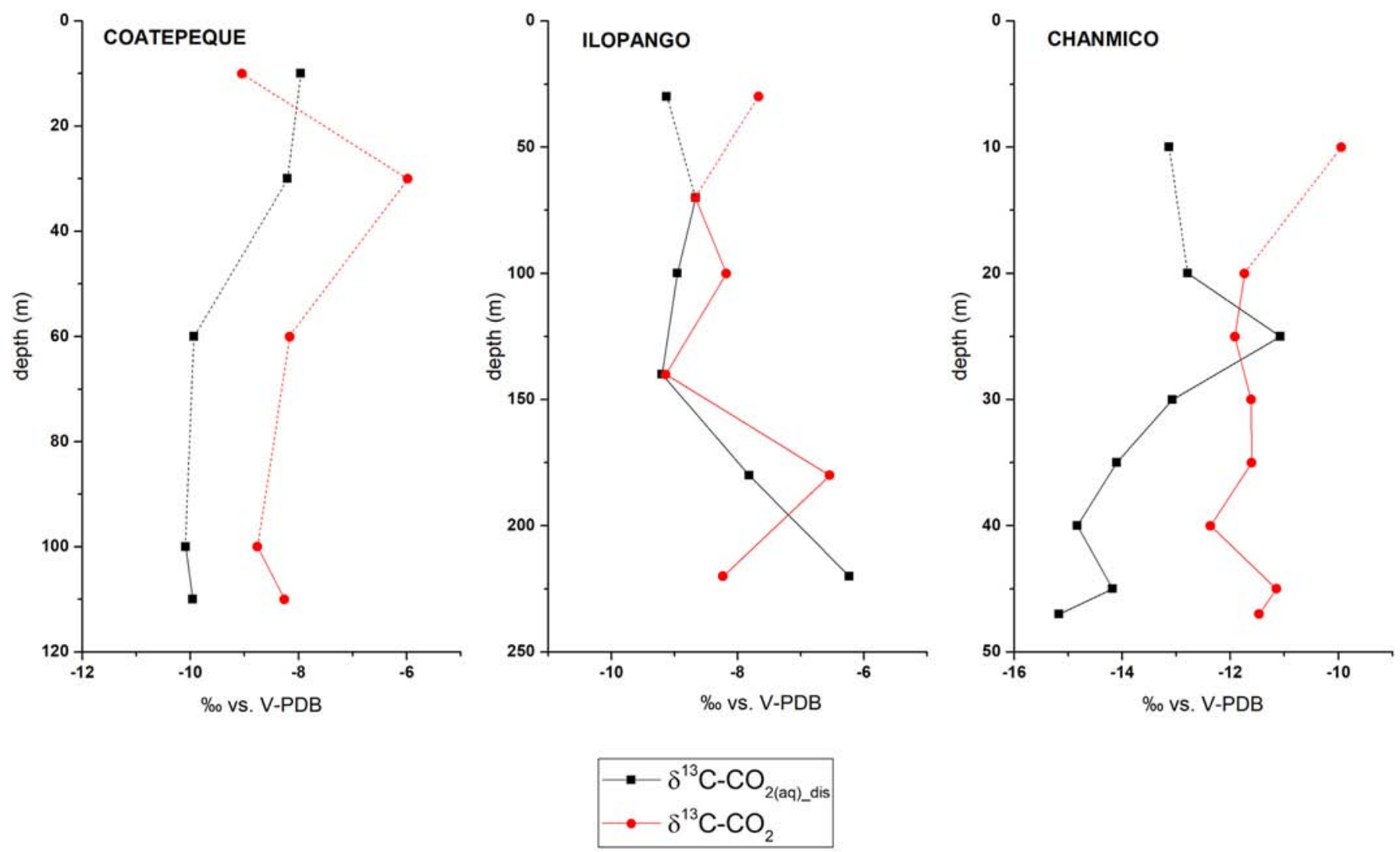

Fig. 12. Vertical profile of the theoretical $\delta^{13} \mathrm{C}_{-} \mathrm{CO}_{2(\text { aq)_dis }}$ vs. measured $\delta^{13} \mathrm{C}-\mathrm{CO}_{2}$ values of the three lakes.

$\mathrm{CO}_{2}$ dissolution, as follows:

$\mathrm{CO}_{2}+\mathrm{H}_{2} \mathrm{O} \rightarrow \mathrm{H}_{2} \mathrm{CO}_{3}$

$\mathrm{H}_{2} \mathrm{CO}_{3}+\mathrm{H}_{2} \mathrm{O} \rightarrow \mathrm{H}_{3} \mathrm{O}^{+}+\mathrm{HCO}_{3}^{-}$

By assuming that the basement below Coatepeque and Ilopango lakes is mainly consisting of Miocene to Pliocene volcanic rocks (Balsamo Formation, Lexa et al., 2011), the concentrations of B, Si, Mn, $\mathrm{Fe}, \mathrm{Co}, \mathrm{Ni}, \mathrm{Cu}, \mathrm{Zn}, \mathrm{As}, \mathrm{Sr}, \mathrm{Ba}$ and $\mathrm{Pb}$ (ordered according to their atomic weight) along the vertical profile of the two lakes were normalized to those of primitive mantle (Palme and O'Neill, 2014) and compared with those measured in the Balsamo basaltic lava samples ("ES 43" and "ES 7" for Coatepeque and Ilopango, respectively; Agostini et al., 2006; Tonarini et al., 2007), equally normalized to the primitive mantle composition. Zinc and As concentrations in the lakes were normalized to those measured in the andesitic basement ("inferior andesites"; Rapprich and Hradecký, 2005) since no data were available for the Balsamo lavas. The spider diagrams of Fig. 8 show that most elements (especially $\mathrm{Fe}$ and $\mathrm{Ni}$ ) were preferentially retained in the host rock or precipitated from the aqueous solution due to the neutral-to-alkaline $\mathrm{pH}$, whereas $\mathrm{B}$ and As, being more mobile, are enriched in the liquid phase, testifying once again an input of hydrothermal fluids inside the lake basins.

\subsubsection{Lake Chanmico}

As shown in the $\delta \mathrm{D}-\mathrm{H}_{2} \mathrm{O}$ vs. $\delta^{18} \mathrm{O}-\mathrm{H}_{2} \mathrm{O}$ diagram (Fig. 9), in which the local meteoric water line and the mean local meteoric water composition (from IAEA/WMO, 2018, San Andres site) are also reported, the $\delta \mathrm{D}$ and $\delta^{18} \mathrm{O}$ positive shifts of Lake Chanmico waters seem to be caused by evaporation processes. Isotope fractionation only affects surface waters, whilst deep waters are preserved to be exposed to air during lake stratification. The propagation along a well-defined line of the evaporating waters was modelized by Lefkowitz et al. (2017), to which attention is drawn here.

It is worth noting that $\mathrm{Mg}^{2+}-\mathrm{HCO}_{3}^{-}$chemistry, such as that of Lake Chanmico, is generally produced by water-rock interaction with mafic or ultramafic rocks, e.g. resulting by the hydrolysis of Mg-bearing silicates (e.g. Barnes et al., 1967; Dotsika et al., 2009). For example, Mgrich waters from two Ethiopian lakes (Hayq and Ardibo) are reported to be originated by leaching processes of strongly altered basalts (Ayenew, 2005 and references therein). Unfortunately, no information about the composition of the rock formations below Lake Chanmico is available, although it is reasonable to assume that the lake substrate consists of basaltic to andesitic rocks associated with the eruptive episodes of the San Salvador volcanic complex (e.g. Ferrés et al., 2013). Nevertheless, $\mathrm{Mg}^{2+}-\mathrm{HCO}_{3}^{-}$waters are also commonly found associated with rocks variably affected by metamorphic processes such as serpentinization (Bruni et al., 2002 and references therein). Maficultramafic igneous ophiolitic complexes (mostly of Cretaceous and pre-Cretaceous age) are known to form part of the basement of Central America, from Guatemala to Panama (e.g. Walther et al., 2000; Alvarado et al., 2007 and references therein).

Serpentine dissolution can be described (Barnes et al., 1967; Marques et al., 2008), as follows:

$\mathrm{Mg}_{3} \mathrm{Si}_{2} \mathrm{O}_{5}(\mathrm{OH})_{4}+6 \mathrm{H}^{+}=3 \mathrm{Mg}^{2+}+2 \mathrm{SiO}_{2}+5 \mathrm{H}_{2} \mathrm{O}$

This process might explain the relatively high $\mathrm{Mg}^{2+}$ and Si concentrations measured in the Chanmico waters, both increasing towards the lake bottom, and those of $\mathrm{B}$, which tends to be enriched in serpentinitic rocks (e.g. Su and Suarez, 2004; Boschetti et al., 2013; Pabst et al., 2015 and references therein). In the $\mathrm{Si}-\mathrm{HCO}_{3}-\mathrm{Mg}$ triangular diagram, where the expected compositions of the aqueous phases produced by dissolution of Mg-bearing solid phases are also reported (modified after Fantoni et al., 2002; Fig. 10), Lake Chanmico shows 
$\mathrm{HCO}_{3}^{-} / \mathrm{Mg}^{2+}$ molar ratios close to 2, i.e. the theoretical value expected for Mg-bearing solid phase, and plots to the left of the serpentine composition. This is apparently confirming the occurrence of serpentine dissolution, in analogy to what reported in other studies (Fantoni et al., 2002; Margiotta et al., 2012; Langone et al., 2013). Such a process can be associated with the precipitation of minerals richer in $\mathrm{SiO}_{2}$ with respect to serpentine. Saturation indexes (calculated through PHREEQC 3.3.7.11094 software using the llnl.dat database; Parkhurst and Appelo, 1999) demonstrate that Lakes Chanmico is oversaturated with respect to sepiolite and talc, undersaturated in typical minerals pertaining to ultramafic rocks (e.g. enstatite and forsterite) and slightly saturated in calcite and quartz (Table 3). The $\mathrm{HCO}_{3}^{-}$increase with depth, coupled with that of dissolved $\mathrm{CO}_{2}$ (Figs. 5-6 and Tables 1-2), may be controlled by the following reaction involving serpentine (e.g. Kojima et al., 1997):

$\mathrm{Mg}_{3} \mathrm{Si}_{2} \mathrm{O}_{5}(\mathrm{OH})_{4}+6 \mathrm{CO}_{2}+\mathrm{H}_{2} \mathrm{O}=3 \mathrm{Mg}^{2+}+6 \mathrm{HCO}_{3}+2 \mathrm{SiO}_{2}$

The primitive mantle-normalized (Palme and O'Neill, 2014) concentrations of $\mathrm{B}, \mathrm{Si}, \mathrm{Mn}, \mathrm{Fe}, \mathrm{Co}, \mathrm{Cu}, \mathrm{Zn}, \mathrm{As}, \mathrm{Sr}, \mathrm{Ba}$ and $\mathrm{Pb}$ along the vertical profile of Lake Chanmico and of a serpentinized peridotite ("SE10_02"; Schwarzenbach et al., 2014) belonging to the Santa Elena Ophiolite (Costa Rica), i.e. the nearest and one of the largest areas of Central America with mafic and ultramafic lithologies, are reported in the spider-diagram of Fig. 11. For B and As rock content, we used as reference serpentinitic rock composition from Boström and Valdes (1969), Bonatti et al. (1984) and Martin et al. (2016). The figure shows that B, $\mathrm{As}, \mathrm{Sr}, \mathrm{Ba}$ and $\mathrm{Pb}$ are more easily mobilized by water-rock interaction processes with respect to $\mathrm{Fe}, \mathrm{Co}$ and $\mathrm{Zn}$, which are basically retained in the host rock or precipitate once in solution. The increase with depth of $\mathrm{Sr}$, Ba and $\mathrm{Pb}$ (Table 1 ) is possibly related to the dissolution of calcite (with $\mathrm{Sr}>\mathrm{Ba}$ and $\mathrm{Pb}$ ), which is commonly associated with serpentinized rocks (e.g. Apollaro et al., 2011), as also suggested by the increase of $\mathrm{Ca}^{2+}$.

Eventually, the increase of ammonium along the vertical profile is likely related to microbial activity occurring in the hypolimnion and within the bottom sediments (Molongoski and Klug, 1980; Buresh and Patrick, 1981; Rysgaard et al., 1994).

\subsection{Processes governing the chemical and isotopic composition of dissolved gases}

Atmospheric gases, i.e. $\mathrm{N}_{2}, \mathrm{O}_{2}$ and $\mathrm{Ar}$, enter the lakes through their surface (Weiss, 1970), a process that is controlled by atmospheric pressure and water and air temperature, and/or as input of sub-lacustrine meteoric-recharged air-saturated springs. Accordingly, Ar showed no significant variations with depth, behaving inertly and being only affected by advection and diffusion processes. A similar behavior was observed for $\mathrm{N}_{2}$. The $\mathrm{N}_{2} / \mathrm{Ar}$ ratios in the Coatepeque, Ilopango and Chanmico lakes are in the range of ASW (air saturated water), confirming that no addition of $\mathrm{N}_{2}$ from an extra-atmospheric source occurred. Oxidative processes, mainly consisting of biological oxidation of organic matter throughout the lakes water body, were likely responsible of the depletion of $\mathrm{O}_{2}$ that produced the anaerobic hypolimnion observed in all the study lakes.

The He/Ar ratio in Lake Coatepeque is up to 0.0019 , i.e. one order of magnitude higher than that of ASW, suggesting an extraatmospheric He source(s), possibly related to the adjacent Santa Ana volcanic system, although this hypothesis should be confirmed by ${ }^{3} \mathrm{He} /{ }^{4} \mathrm{He}$ values, which were not available for the present study. On the contrary, the He/Ar ratios of Ilopango and Chanmico lakes are in the range of ASW. The increasing concentrations of $\mathrm{H}_{2}$ with depth measured in all the study lakes were likely related to mineralization processes of organic matter under anaerobic conditions at the water-sediment interface and activity of microbial populations that used this gas as electron donor (Mah et al., 1977; Zehnder, 1978; Thauer and Badziong, 1980).

The Coatepeque, Ilopango and Chanmico deep waters are characterized by significant concentrations of dissolved $\mathrm{CO}_{2}$ and $\mathrm{CH}_{4}$, which is a common feature of lakes hosted in quiescent volcanic systems (e.g. Cabassi et al., 2013, 2014; Tassi and Rouwet, 2014). The highest $\mathrm{CO}_{2}$ concentrations at the maximum lake depths (Table 2) are consistent with the addition of an extra-lacustrine $\mathrm{CO}_{2}$ source from the lake bottom, according to: i) lake water chemistry (see previous section) and ii) $\delta^{13} \mathrm{C}_{-} \mathrm{CO}_{2}$ values (Table 2 ), which are significantly less negative than those typically produced by biogenic processes $\left(\delta^{13} \mathrm{C}-\mathrm{CO}_{2} \leq-20 \%\right.$ ovs. V-PDB; Faure, 1986; O'Leary, 1988; Hoefs, 2009) and consistent with the isotopic value measured at Cerro Pacho, close to Lake Coatepeque $\left(\delta^{13} \mathrm{C}-\mathrm{CO}_{2}=-10.7 \%\right.$ ). The concentration of $\mathrm{CO}_{2}$ at the bottom of the three Salvadorian lakes is however lower than that observed in other volcanic lakes hosting gas reservoirs at depth (e.g. Lake Kivu, Tassi et al., 2009; Italian lakes, Cabassi et al., 2013; Costa Rican lakes, Cabassi et al., 2014; Lake Pavin, Zimmer et al., 2015; Table 4), although this gas significantly increased with depth in all the study lakes (Table 2).

In order to elucidate the processes controlling the $\delta^{13} \mathrm{C}_{-} \mathrm{CO}_{2}$ values of the lakes waters, the isotope mass balance and the measured $\delta^{13} \mathrm{C}$-TDIC values were used to compute the $\delta^{13} \mathrm{C}$ values of $\mathrm{CO}_{2(\mathrm{aq})}$ resulting from $\mathrm{CO}_{2(\mathrm{~g})}$ dissolution $\left(\delta^{13} \mathrm{C}-\mathrm{CO}_{2(\mathrm{aq}) \_d i s}\right)$, as explained in detail in Venturi et al. (2017), as follows:

$\delta^{13} \mathrm{C}-\mathrm{CO}_{2(\mathrm{aq}) \_\mathrm{dis}}=\delta^{13} \mathrm{C}-\mathrm{TDIC}-\varepsilon_{2} \times\left(\mathrm{HCO}_{3}{ }^{-}\right) /(\mathrm{TDIC})$

where $\mathrm{HCO}_{3}$ and TDIC are in $\mathrm{mmol} / \mathrm{L}$ and the enrichment factor $\varepsilon_{2}$ quantifies the isotopic fractionation caused by the reaction between dissolved $\mathrm{CO}_{2}$ and $\mathrm{HCO}_{3}^{-}$(Mook et al., 1974), as follows:

$\varepsilon_{2}=\delta^{13} \mathrm{C}-\mathrm{HCO}_{3}{ }^{-}-\delta^{13} \mathrm{C}-\mathrm{CO}_{2}=9866 / \mathrm{T}(\mathrm{K})-24.12$

The theoretical $\delta^{13} \mathrm{C}_{-} \mathrm{CO}_{2(\mathrm{aq}) \_d i s}$ values of the three lakes are compared with the measured $\delta^{13} \mathrm{C}-\mathrm{CO}_{2}$ values in Fig. 12. The discordancy between measured and calculated values, suggesting that no isotopic equilibrium between $\mathrm{CO}_{2}$ and the dissolved carbonate species is achieved, is particularly large for waters from Lake Chanmico, likely due to (bio)chemical processes affecting the chemical equilibrium of reaction (6), as already documented for other volcanic lakes (e.g. Tassi et al., 2009; Cabassi et al., 2013, 2014). Such an isotopic disequilibrium is also confirmed by the comparison of measured vs. theoretical $\mathrm{pH}$ values, the latter being calculated assuming the equilibrium at the following reaction:

$\mathrm{CO}_{2(\mathrm{aq})}+\mathrm{H}_{2} \mathrm{O}=\mathrm{H}^{+}+\mathrm{HCO}_{3}^{-}$

and using the Henderson-Hasselbalch equation (Po and Senozan, 2001 and references therein):

$\mathrm{pH}=\mathrm{pKa}+\log \left[\mathrm{HCO}_{3}{ }^{-}\right] /\left[\mathrm{CO}_{2}\right]$

The results show that the difference between theoretical and measured $\mathrm{pH}$ values for Lake Chanmico is up to 1.9 , which is likely determined by biogeochemical reactions controlling the carbon cycle within Lake Chanmico involving both $\mathrm{CO}_{2}$ and $\mathrm{CH}_{4}$. These concentrations are higher than those of $\mathrm{CO}_{2}$ towards the lake bottom. In fact, such a relatively high $\mathrm{CH}_{4}$ content, being one and two orders of magnitude higher than that at Coatepeque and Ilopango, respectively, and in the range of that measured in Monticchio Grande, Albano and Hule volcanic lakes (Table 4), suggests the occurrence of bacterial methanogenesis, although this hypothesis should be confirmed by $\delta^{13} \mathrm{C}^{-} \mathrm{CH}_{4}$ and $\delta \mathrm{D}-\mathrm{CH}_{4}$ (e.g. Schoell, 1980; Schoell et al., 1988), which are not available for this study. A biogenic source at Lake Chanmico is also consistent with the $\delta^{13} \mathrm{C}$-TDIC values (Table 1 ), being significantly 
more negative than those of the other two lakes. However, substantial amounts of $\mathrm{CH}_{4}$ could also be produced through catalyzed abiotic methanation at low temperatures, a process known to be occurring on serpentinized ultramafic rocks (Etiope et al., 2011, 2013) that likely caused the peculiar water chemistry of the lake.

\section{Conclusions}

This study presented an exhaustive chemical and isotopic dataset of Coatepeque, Ilopango and Chanmico volcanic lakes (El Salvador), which showed peculiar chemical compositions, i.e. $\mathrm{Na}^{+}-\mathrm{Cl}^{-}$and $\mathrm{Mg}^{2+}-\mathrm{HCO}_{3}^{-}$, respectively.

The chemical composition of Coatepeque and Ilopango lakes resembled those of fluids related to geothermal and/or volcanic systems (e.g. relatively high TDS values, $\mathrm{Cl}^{-} / \mathrm{Br}^{-}$molar ratios $\leq 650$, high As, B, Li and Si concentrations and $\mathrm{Cl}^{-} / \mathrm{SO}_{4}^{2-}$ ratio $>1$ ), whereas the $\mathrm{Mg}^{2+}-\mathrm{HCO}_{3}^{-}$ waters of Lake Chanmico are likely originated through interaction processes with mafic/ultramafic rocks affected by serpentinization, which allowed to explain the high $\mathrm{Mg}^{2+}, \mathrm{Si}$ and $\mathrm{B}$ concentrations. To the best of our knowledge, such chemical compositions are rather unique for volcanic lakes hosted in quiescent volcanic systems. The $\delta \mathrm{D}-\mathrm{H}_{2} \mathrm{O}$ vs. $\delta^{18} \mathrm{O}-\mathrm{H}_{2} \mathrm{O}$ values indicate that the lakes waters are affected by evaporation processes. The relatively stable stratification of the lake waters favors the development of anoxic hypolimnion, characterized by the presence of $\mathrm{CO}_{2}$, even if in smaller quantities with respect to other meromictic volcanic lakes (e.g. Lake Kivu in DRC, Monticchio, Albano and Averno lakes in Italy, Hule and Rio Cuarto lakes in Costa Rica, Lake Pavin in France), and $\mathrm{CH}_{4}$, whose concentrations in Lake Chanmico are up to two orders of magnitude higher than those of Coatepeque and Ilopango lakes, suggesting bacterial methanogenesis. However, the $\delta^{13} \mathrm{C}_{-} \mathrm{CO}_{2}$ values of the lakes are consistent with the addition of an extra-lacustrine $\mathrm{CO}_{2}$ source from the bottom.

However, further investigations regarding $\mathrm{i}$ ) the isotopic signature of helium and methane $\left(\delta^{13} \mathrm{C}-\mathrm{CH}_{4}\right.$ and $\delta \mathrm{D}-\mathrm{CH}_{4}$ values $)$ and ii) the presence and distribution along the water column of the microbial populations would help to shed light on the overall biogeochemical processes acting inside the water bodies of the three lakes from El Salvador.

\section{Acknowledgements}

This work was financially supported by the laboratories of Fluid Geochemistry and Stable Isotopes of the Department of Earth Sciences of the University of Florence and CNR-IGG and the Cooperation Project between Italy and El Salvador "Sa.Pe.Vo." (Resp. AC). We greatly appreciated the suggestions and precise corrections of the reviewers, whom we thank very much.

\section{References}

Aggarwal, J.K., Palmer, M.R., Bullen, T.D., Arnosson, S., Ragnarsdottir, K.V., 2000. The boron isotope systematic of Icelandic geothermal waters: 1 . Meteoric water charged systems. Geochim. Cosmochim. Acta 64, 579-585.

Agostini, S., Corti, G., Doglioni, C., Carminati, E., Innocenti, F., Tonarini, S., Manetti, P., Di Vincenzo, G., Montanari, D., 2006. Tectonic and magmatic evolution of the active volcanic front in El Salvador: insight into the Berlin and Ahuachapan geothermal areas. Geothermics 35, 368-408.

Aiuppa, A., Avino, R., Brusca, L., Caliro, S., Chiodini, G., D'Alessandro, W., Favara, R., Federico, C., Ginevra, W., Inguaggiato, S., Longo, M., Pecoraino, G., Valenza, M., 2006. Mineral control of arsenic content in thermal waters from volcano-hosted hydrothermal systems: insights from Island of Ischia and Phlegrean Fields (Campanian Volcanic Province, Italy). Chem. Geol. 229, 313-330.

Aleman Alberto, E.M., Guerrero Nolasco, E.N., 2007. Evaluación de la calidad del agua en el Lago de Coatepeque en el periodo de Junio-Agosto de 2006.

Alvarado, G.E., Dengo, C., Martens, U., Bundschuh, J., Aguilar, T., Bonis, S.B., 2007. Stratigraphy and geologic history. In: Bundschuh, J., Alvarado, G.E. (Eds.), Central America: Geology, Resources and Hazards. vol. 1. Taylor \& Francis, London, pp. 345-394.

Ambury, L., 2017. Correlating the vertical water column temperature to water color change event of Caldera Lake Coatepeque, El Salvador. US Hydro 2017 Conference, Galveston, TX.

Anzidei, M., Carapezza, M.L., Esposito, A., Giordano, G., Tarchini, L., Lelli, M., 2008. The Albano Maar lake high resolution bathymetry and dissolved $\mathrm{CO}_{2}$ budget (Colli Albani
District, Italy): constrains to hazard evolution. J. Volcanol. Geotherm. Res. 171, 258-268.

Apollaro, C., Marini, L., Critelli, T., Barca, D., Bloise, A., De Rosa, R., Liberi, F., Miriello, D., 2011. Investigation of rock-to-water release and fate of major, minor, and trace elements in the metabasalt-serpentinite shallow aquifer of Mt. Reventino (CZ, Italy) by reaction path modelling. Appl. Geochem. 26 (9-10), 1722-1740.

Ayenew, T., 2005. Major ions composition of the groundwater and surface water systems and their geological and geochemical controls in the Ethiopian volcanic terrain. SINET Ethiop. J. Sci. 28 (2), 171-188.

Barnes, I., LaMarche Jr., V.C., Himmelberg, G.R., 1967. Geochemical evidence of presentday serpentinization. Science 56, 830-832.

Bernard, A., Escobar, C.D., Mazot, A., Guttiérrez, R.E., 2004. The acid crater lake of Santa Ana volcano, El Salvador. Geol. Soc. Am. Spec. Pap. 375, 121-133.

Bonatti, E., Lawrence, J.R., Morandi, N., 1984. Serpentinization of oceanic peridotites: temperature dependence of mineralogy and boron content. Earth Planet. Sci. Lett. 70, $88-94$.

Boschetti, T., Etiope, G., Pennisi, M., Romain, M., Toscani, L., 2013. Boron, lithium and methane isotope composition of hyperalkaline waters (Northern Apennines, Italy): terrestrial serpentinization or mixing with brine? Appl. Geochem. 32, 17-25.

Boström, K., Valdes, S., 1969. Arsenic in ocean floors. Lithos 2 (4), 351-360.

Brondi, M., Dall'Aglio, M., Vitrani, F., 1973. Lithium as pathfinder element in the large scale hydrothermal exploration for hydrothermal systems. Geothermics 2, 142-153.

Bruni, J., Canepa, M., Chiodini, G., Cioni, R., Cipolli, F., Longinelli, A., Marini, L., Ottonello, G., Vetuschi Zuccolini, M., 2002. Irreversible water-rock mass transfer accompanying the generation of the neutral $\mathrm{Mg}-\mathrm{HCO}_{3}$ and high-pH, $\mathrm{Ca}-\mathrm{OH}$ spring waters of the Génova province Italy. Appl. Geochem. 17, 455-474.

Buresh, R.J., Patrick, W.H., 1981. Nitrate reduction to ammonium and organic nitrogen in an estuarine sediment. Soil Biol. Biochem. 13, 279-283.

Cabassi, J., Tassi, F., Vaselli, O., Fiebig, J., Nocentini, M., Capecchiacci, F., Rouwet, D., Bicocchi, G., 2013. Biogeochemical processes involving dissolved $\mathrm{CO}_{2}$ and $\mathrm{CH}_{4}$ at Albano, Averno, Monticchio meromictic volcanic lakes (Central-Southern Italy). Bull. Volcanol. 75, 683

Cabassi, J., Tassi, F., Mapelli, F., Borin, S., Calabrese, S., Rouwet, D., Chiodini, G., Marasco, R. Chouala, B., Avino, R., Vaselli, O., Pecoraino, G., Capecchiacci, F., Bicocchi, G., Caliro, S., Ramirez, C., Mora-Amador, R., 2014. Geosphere-biosphere interactions in bio-activity volcanic lakes: evidences from Hule and Rio Cuarto (Costa Rica). PLoS One 9 (7), e102456.

Caliro, S., Chiodini, G., Izzo, G., Minopoli, C., Signorini, A., Avino, R., Granieri, D., 2008. Geochemical and biochemical evidence of lake turnover and fish kill at Lake Averno, Italy. J. Volcanol. Geotherm. Res. 178, 305-316.

Christenson, B., 2000. Geochemistry of fluids associated with the 1995/96 eruption of Mt. Ruapheu, New Zealand: signatures and processes in the magmatic-hydrothermal system. J. Volcanol. Geotherm. Res. 97, 1-30.

Christenson, B., Tassi, F., 2015. In: Rouwet, D., Christenson, B., Tassi, F., Vandemeulebrouck, J. (Eds.), Gases in volcanic lake environments. "Volcanic Lakes, Advances in Volcanology". Springer-Heidelberg, pp. 125-153 https://doi.org/ 10.1007/978-3-642-36833-2 2

Cinti, D., Poncia, P.P., Brusca, L., Tassi, F., Quattrocchi, F., Vaselli, O., 2015. Spatial distribution of arsenic, uranium and vanadium in the volcanic-sedimentary aquifers of the Vicano-Cimino Volcanic District (Central Italy). J. Geochem. Explor. 152, 123-133.

Cinti, D., Tassi, F., Procesi, M., Brusca, L., Cabassi, J., Capecchiacci, F., Delgado Huertas, A., Galli, G., Grassa, F., Vaselli, O., Voltattorni, N., 2017. Geochemistry of hydrothermal fluids from the eastern sector of the Sabatini Volcanic District (central Italy). Appl. Geochem. 84, 187-201.

Colvin, A., Rose, W.I., Varekamp, J.C., Palma, J.L., Escobar, D., Gutiérrez, E., Montalvo, F., Maclean, A., 2013. Crater lake evolution at Santa Ana volcano following the 2005 eruption. In: Rose, W.I., Palma, J.L., Delgado Granados, H., Varley, N. (Eds.), Understanding Open Vent Volcanism and Related Hazards. Geol Soc America Special Paper 498(2), pp. 23-44 https://doi.org/10.1130/2013.2498(00).

Corti, G., Carminati, E., Mazzarini, F., Oziel Garcia, M., 2005. Active strike-slip faulting in El Salvador, Central America. Geology 33 (12), 989-992. https://doi.org/10.1130/ G21992.1.

Costa, A Chiodini, G , 2015. Modelling air dispersion of $\mathrm{CO}_{2}$ from limnic eruptions. In: Rouwet, D., Christenson, B., Tassi, F., Vandemeulebrouck, J. (Eds.), Volcanic Lakes, Advances in Volcanology. Springer-Heidelberg, pp. 451-465 https://doi.org/10.1007/ 978-3-642-36833-2 2

Davis, S.N., Cecil, L.D., Zreda, M., Moysey, S., 2001. Chlorine-36, bromide, and the origin of spring water. Chem. Geol. 179, 3-16

Dotsika, E., Poutoukis, D., Tzavidopoulos, I., Maniatis, Y., Ignatiadou, D., Raco, B., 2009. A natron source at Pikrolimni Lake in Greece? Geochemical evidence. J. Geochem. Explor. 103, 133-143.

Dull, R., Southon, J.R., Kutterolf, S., Freundt, A., Wahl, D., Sheets, P., 2010. Did the TBJ Ilopango eruption cause the AD 536 event? American Geophysical Union, Fall Meeting 2010, Abstract \#V13C-2370

Esquivel, I., 2016. Levantamiento batimétrico y medición de parámetros físico-químicos en el Lago de Ilopango, El Salvador. Bachelor thesis. Universidad de El Salvador.

Etiope, G., Schoell, M., Hosgörmez, H., 2011. Abiotic methane flux from the Chimaera seep and Tekirova ophiolites (Turkey): understanding gas exhalation from low temperature serpentinization and implications for Mars. Earth Planet. Sci. Lett. 310 (1-2), 96-104.

Etiope, G., Ehlmann, B.L., Schoell, M., 2013. Low temperature production and exhalation of methane from serpentinized rocks on Earth: a potential analog for methane production on Mars. Icarus 224 (2), 276-285.

Evans, W.C., White, L.D., Rapp, J.B., 1998. Geochemistry of some gases in hydrothermal fluids from the southern Juan de Fuca ridge. J. Geophys. Res. 15, 305-313. 
Fantoni, D., Brozzo, G., Canepa, M., Cipolli, F., Marini, L., Ottonello, G., Vetuschi Zuccolini, M., 2002. Natural hexavalent chromium in groundwaters interacting with ophiolitic rocks. Environ. Geol. 42, 871-882.

Faure, G., 1986. Inorganic Geochemistry. Macmillan Pub Com, p. 627.

Ferrés, D., Delgado Granados, H., Hernández, W., Pullinger, C., Chávez, H., Castillo Taracena, C.R., Cañas-Dinarte, C., 2011. Three thousand years of flank and central vent eruptions of the San Salvador volcanic complex (El Salvador) and their effects on El Cambio archeological site: a review based on tephrostratigraphy. Bull. Volcanol. 73, 833. https://doi.org/10.1007/s00445-011-0465-0.

Ferrés, D., Delgado Granados, H., Gutiérrez, R.E., Farraz, I.A., Hernández, E.W., Pullinger, C.R., Escobar, C.D., 2013. Explosive volcanic history and hazard zonation maps of Boquerón Volcano (San Salvador volcanic complex, El Salvador). In: Rose, W.I. Palma, J.L., Delgado Granados, H., Varley, N. (Eds.), Understanding Open-vent Volcanism and Related Hazards: Geological Society of America Special Paper. vol. 498, pp. 201-230. https://doi.org/10.1130/2013.2498(12).

Fontes, J.C., Matray, J.M., 1993. Geochemistry and origin of formation brines from the Paris Basin, France. Chem. Geol. 109, 177-200.

FORGAES \& SNET, 2006. Investigaciones hidrogeológicas, hidrológicas e hidroquímicas en el Lago Coatepeque. Unión Europea (Resumen ejecutivo).

Göb, S., Loges, A., Nolde, N., Bau, M., Jacob, D.E., Markl, G., 2013. Major and trace element compositions (including REE) of mineral, thermal, mine and surface waters in SW Germany and implications for water-rock interaction. Appl. Geochem. 33, 127-152.

Grassa, F., Capasso, G., Oliveri, Y., Sollami, A., Carreira, P., Carvalho, M.R., Marques, J.M., Nunes, J.C., 2010. Nitrogen isotopes determination in natural gas: analytical method and first results on magmatic, hydrothermal and soil gas samples. Isot. Environ. Health Stud. 46 (2), 141-155.

Hernández, P.A., Pérez, N.M., Varekamp, J.C., Henriquez, B., Hernández, A., Barrancos, J., Padron, E., Calvo, D., Melian, G., 2007. Crater lake temperature changes of the 2005 eruption of Santa Ana Volcano, El Salvador, Central America. Pure Appl. Geophys. 164, 2507-2522

Hoefs, J., 2009. Stable Isotope Geochemistry. 6th edn. Springer, Berlin, p. 288.

IAEA/WMO, 2018. Global Network of Isotopes in Precipitation. The GNIP Database Accessible at:. https://nucleus.iaea.org/wiser.

Kling, G.W., Evans, W.C., Tanyileke, G.Z., 2015. The comparative limnology of Lakes Nyos and Monoun, Cameroon. In: Rouwet, D., Christenson, B., Tassi, F., Vandemeulebrouck, J. (Eds.), Volcanic Lakes, Advances in Volcanology. Springer-Heidelberg, pp. 401-425 https://doi.org/10.1007/978-3-642-36833-2_2.

Kojima, T., Nagamine, A., Ueno, N., Uemiya, S., 1997. Absorption and fixation of carbon dioxide by rock weathering. Energy Convers. Manag. 38, S461-S466.

Kusakabe M (2015) Evolution of $\mathrm{CO}_{2}$ content in Lakes Nyos and Monoun, and sublacustrine $\mathrm{CO}_{2}$-recharge system at Lake Nyos as Envisaged from $\mathrm{CO}_{2} /{ }^{3} \mathrm{He}$ ratios and noble gas signatures. "Volcanic Lakes, Advances in Volcanology,". Ed: D. Rouwet, B. Christenson, F. Tassi, J. Vandemeulebrouck, DOI https://doi.org/10.1007/978-3-64236833-2_2, Springer-Heidelberg, 427-450.

Laiolo, M., Coppola, D., Barahona, F., Benítez, J.E., Cigolini, C., Escobar, D., Funes, R., Gutierrez, E., Henriquez, B., Hernandez, A., Montalvo, F., Olmos, R., Ripepe, M., Finizola, A., 2017. Evidences of volcanic unrest on high-temperature fumaroles by satellite thermal monitoring: the case of Santa Ana volcano, El Salvador. J. Volcanol. Geotherm. Res. 340, 170-179.

Langelier, W., Ludwig, H., 1942. Graphical methods for indicating the mineral character of natural waters. J. Am. Water Assoc. 34, 335-352.

Langone, A., Baneschi, I., Boschi, C., Dini, A., Guidi, M., Cavallo, A., 2013. Serpentinite-water interaction and chromium(VI) release in spring waters: examples from Tuscan ophiolites. Ofioliti 38 (1), 41-57. https://doi.org/10.4454/ofioliti.v38i1.415.

Lefkowitz, J.N., Varekamp, J.C., Reynolds, R.W., Thomas, E., 2017. A tale of two lakes: the Newberry Volcano twin crater lakes, Oregon, USA. Geol. Soc. Lond., Spec. Publ. 437 (1), 253-288.

Lexa, J., Šebesta, J., Chavez, J., Hernandez, W., Pécskay, Z., 2011. Geology and volcanic evolution in the southern part of the San Salvador Metropolitan Area. J. Geosci. 56 105-140.

Lopez, D.L., Ransom, L., Pérez, N.M., Hernández, P.A., Monterrosa, J., 2004. Dynamics of diffuse degassing at Ilopango Caldera, El Salvador. In: Rose, W.I., Bommer, J.J., Lopez, D.L., Carr, M.J., Major, J.J. (Eds.), Natural Hazards in El Salvador. Boulder, Colorado. Geological Society of America Special Paper 375, pp. 191-202.

Lopez, D.L., Ransom, L., Monterrosa, J., Soriano, T., Barahona, F., Olmos, R., Bundschuh, J. 2009. Volcanic arsenic and boron pollution of Ilopango Lake, El Salvador. In: Natural Arsenic in Groundwaters of Latin America. Arsenic in the Environment, 1. Taylor \& Francis (CRC Press), London, United Kingdom, pp. 129-143.

Lopez, D.L., Bundschuh, J., Birkle, P., Armienta, M.A., Cumbal, L., Sracek, O., Cornejo, L., Ormachea, M., 2012. Arsenic in volcanic geothermal fluids of Latin America. Sci. Total Environ. 429, 57-75.

Mah, R.A., Ward, D.M., Baresi, L., Glass, T.L., 1977. Biogenesis of methane. Annu. Rev. Microbiol. 31, 309-341.

Mann, C.P., Stix, J., Vallance, J.W., Richer, M., 2004. Subaqueous intracaldera volcanism, Ilopango Caldera, El Salvador, Central America. In: Rose, W.I., Bommer, J.J., Lopez, D.L., Carr, M.J., Major, J.J. (Eds.), Natural Hazards in El Salvador. Geological Society of America, Boulder, Colorado, pp. 159-174 Special Paper 375.

Margiotta, S., Mongelli, G., Summa, V., Paternoster, M., Fiore, S., 2012. Trace element distribution and $\mathrm{Cr}(\mathrm{VI})$ speciation in $\mathrm{Ca}-\mathrm{HCO}_{3}$ and $\mathrm{Mg}-\mathrm{HCO}_{3}$ spring waters from the northern sector of the Pollino massif, southern Italy. J. Geochem. Explor. 115, $1-12$.

MARN, 2017. Informe técnico sobre cambio de color en las aguas del Lago de Coatepeque Technical report. Ministerio de Medio Ambiente y Recursos Naturales de El Salvador.

Marques, J.M., Carreira, P.M., Carvalho, M.R., Matias, M.J., Goff, F.E., Basto, M.J., Graça, R.C., Aires-Barros, L., Rocha, L., 2008. Origins of high pH mineral waters from ultramafic rocks, Central Portugal. Appl. Geochem. 23, 3278-3289.
Martin, C., Flores, K.E., Harlow, G.E., 2016. Boron isotopic discrimination for subductionrelated serpentinites. Geology 44 (11), 899-902.

Martínez-Hackert, B., Bajo Sanchez, J.V., Figueroa, C., 2017. Active volcanoes under wate and inland: using hydrography on Coatepeque Caldera Lake, El Salvador. US Hydro 2017 Conference, Galveston, TX

Molongoski, J.J., Klug, M.J., 1980. Anaerobic metabolism of particulate organic matter in the sediments of a hypereutrophic lake. Freshw. Biol. 10, 507-518.

Mook, W.G., Bommerson, J.C., Staverman, W.H., 1974. Carbon isotope fractionation between dissolved bicarbonate and gaseous carbon dioxide. Earth Planet. Sci. Lett. 22, $169-176$.

O'Leary, M.H., 1988. Carbon isotopes in photosynthesis. BioScience 38, 328-336.

Pabst, S., Zack, T., Savov, I., et al., 2015. Evidence for boron incorporation into the serpentine crystal structure. Am. Mineral. 96 (7), 1112-1119. https://doi.org/10.2138/ am.2011.3709.

Palme, H., O'Neill, H., 2014. Cosmochemical estimates of mantle composition. Treatise on Geochemistry, 2nd edition Elsevier.

Parkhurst, D.L., Appelo, C.A.J., 1999. User's Guide to PHREEQC, Version 2: A Computer Program for Speciation, Batch-reaction, One-dimensional Transport, and Inverse Geochemical Calculations. U.S. Geol. Surv.: Earth Sci. Information Center, Open-File Reports Section (Distributor).

Pasternack, G.B., Varekamp, J.C., 1997. Volcanic lake systematic I. Physical constraints Bull. Volcanol. 58, 528-538.

Paternoster, M., Mongelli, G., Caracausi, A., Favara, R., 2016. Depth influence on the distribution of chemical elements and saturation index of mineral phases in twins maa lakes: the case of the Monticchio lakes (southern Italy). J. Geochem. Explor. 163, $10-18$.

Po, H.N., Senozan, N.M., 2001. The Henderson-Hasselbalch equation: its history and limitations. J. Chem. Educ. 78 (11), 1499.

Pullinger, C., 1998. Evolution of the Santa Ana Volcanic Complex, El Salvador. Michigan Technological University (M. Sc. in Geology).

Ransom, L., 2002. Volcanic Diffuse Soil Degassing and Lake Chemistry of the Ilopango Caldera System, El Salvador, Central America. MSc Thesis. Ohio University, Athens $(\mathrm{OH})$.

Rapprich, V., Hradecký, P., 2005. The Cinotepeque Range of central El Salvador: geology, magma origin, and volcanism. Bull. Geosci. 80, 277-286.

Richer, M., Mann, C.P., Stix, J., 2004. Mafic magma injection triggers eruption at Ilopango Caldera, El Salvador, Central America. In: Rose, W.I., Bommer, J.J., Lopez, D.L., Carr, M.J., Major, J.J. (Eds.), Natural Hazards in El Salvador. Boulder, Colorado, Geological Society of America Special Paper vol. 375, pp. 175-189.

Risacher, F., Fritz, B., Hauser, A., 2011. Origin of components in Chilean thermal waters. J. S. Am. Earth Sci. 31, 153-170.

Rodriguez, R., Olmos, R., Payes, J., 2014. Medición de gas Radón $\left(\mathrm{Rn}^{222}\right)$ en aguas termales del Cerro Pacho, Caldera Coatepeque, El Salvador. Rev. Geol. Am. Central 50, 71-82.

Rouwet, D., 2013. VOLADA - a collaborative data base on Volcanic Lakes. https://vhub.org/ resources/2437.

Rouwet, D., Tassi, F., 2014. An overview of the structure, hazards, and methods of investigation of Nyos-type lakes from the geochemical perspective. J. Limnol. 73 (1) https://doi.org/10.4081/jlimnol.2014.836.

Rouwet, D., Tassi, F., Mora-Amador, R., Sandri, L., Chiarini, V., 2014. Past, present and future of volcanic lake monitoring. J. Volcanol. Geotherm. Res. 272, 78-97.

Rowe, G.L., Ohsawa, S., Takano, B., Brantley, S.L., Fernandez, J.F., Barquero, J., 1992. Using crater lake chemistry to predict volcanic activity at Poás volcano, Costa Rica. Bull. Volcanol. 54, 494-503

Rysgaard, S., Risgaard-Petersen, N., Sloth, N.P., Jensen, K., Nielsen, L.P., 1994. Oxygen regulation of nitrification and denitrification in sediments. Limnol. Oceanogr. 39, $1643-1652$.

Salata, G.G., Roelke, L.A., Cifuentes, L.A., 2000. A rapid and precise method for measuring stable carbon isotope ratios of dissolved inorganic carbon. Mar. Chem. 69, 153-161.

Salazar, J.M.L., Hernández, P.A., Pérez, N.M., Olmos, R., Barahona, F., Cartagena, R., Soriano T., López, D.L., Sumino, H., Notsu, K., 2004. Spatial and temporal variations of diffuse $\mathrm{CO}_{2}$ degassing at Santa Ana-Izalco-Coatepeque volcanic complex, El Salvador, Centra America. In: Rose, W.I., Bommer, J.J., Lopez, D.L., Carr, M.J., Major, J.J. (Eds.), Natura Hazards in El Salvador. Boulder, Colorado, Geological Society of America Special Paper vol. 375, pp. 129-149.

Saxby, J., Gottsmann, J., Cashman, K., Gutiérrez, E., 2016. Magma storage in a strike-slip caldera. Nat. Commun. 7, 12295. https://doi.org/10.1038/ncomms12295.

Schoell, M., 1980. The hydrogen and carbon isotopic composition of methane from natural gases of various origins. Geochim. Cosmochim. Acta 44, 646-661.

Schoell, M., Tietze, K., Schoberth, S., 1988. Origin of the methane in Lake Kivu (east-central Africa). Chem. Geol. 71, 257-265.

Schwarzenbach, E.M., Gazel, E., Caddick, M.J., 2014. Hydrothermal processes in partially serpentinized peridotites from Costa Rica: evidence from native copper and complex sulfide assemblages. Contrib. Mineral. Petrol. 168, 1079. https://doi.org/10.1007/ s00410-014-1079-2.

Scolamacchia, T., Pullinger, C., Caballero, L., Montalvo, F., Beramendi Orosco, L.E., González Hernández, G., 2010. The 2005 eruption of Llamatepec (Santa Ana) volcano, E Salvador. J. Volcanol. Geotherm. Res. 189, 291-318.

SNET, 2000. Cuerpos de Agua Continentales de El Salvador. Report. Servicio Nacional de Estudios Territoriales, El Salvador.

Sofield, D.J., 1998. History and Hazards of San Salvador Volcano, El Salvador. Thesis of Master of Science in Geology. Michigan Technological University.

Sriwana, T., van Bergen, M.J., Varekamp, J.C., Sumarti, S., Takano, B., Van Os, B.J.H., Leng, M.J., 2000. Geochemistry of the acid Kawah Putih Lake, Patuha volcano, West Java, Indonesia. J. Volcanol. Geotherm. Res. 97, 77-104.

Su, C., Suarez, D., 2004. Boron release from weathering illites, serpentine, shales, and illitic/palygorskitic soils. Soil Sci. Soc. Am. J. 68 (1), 96-105. 
Tassi, F., Rouwet, D., 2014. An overview of the structure, hazards, and methods of investigation of Nyos-type lakes from the geochemical perspective. J. Limnol. 73 (1), 39-54.

Tassi F, Vaselli O, Luchetti G, Montegrossi G, Minissale A (2008) Metodo per la determinazione dei gas disciolti in acque naturali. Int Rep CNR-IGG, Florence, $n^{\circ}$ 10450, pp. 11. (In Italian).

Tassi, F., Vaselli, O., Tedesco, D., Montegrossi, G., Darrah, T., Cuoco, E., Mapendano, M. Poreda, R., Delgado Huertas, A., 2009. Water and gas chemistry at Lake Kivu (DRC): geochemical evidence of vertical and horizontal heterogeneities in a multi-basin structure. Geochem. Geophys. Geosyst. 10 (2). https://doi.org/10.1029/ 2008GC002191.

Tassi, F., Fazi, S., Rossetti, S., Pratesi, P., Ceccotti, M., Cabassi, J., et al., 2018a. The biogeochemical vertical structure renders a meromictic volcanic lake a trap for geogenic $\mathrm{CO}_{2}$ (Lake Averno, Italy). PLoS One 13 (3), e0193914. https://doi.org/10.1371/journal.pone.0193914.

Tassi, F., Cabassi, J., Andrade, C., Callieri, C., Silva, C., Viveiros, F., Corno, G., Vaselli, O., Selmo, E., Gallorini, A., Ricci, A., Giannini, L., Cruz, J.V., 2018b. Mechanisms regulating $\mathrm{CO}_{2}$ and $\mathrm{CH}_{4}$ dynamics in the Azorean volcanic lakes (São Miguel Island, Portugal). J. Limnol. https://doi.org/10.4081/jlimnol.2018.1821.

Thauer, R.K., Badziong, W., 1980. Respiration with sulfate as electron acceptor. In: Knowles, C.J. (Ed.), Diversity of Bacterial Respiratory Systems. CRC, Boca Raton, pp. 65-85.

Tonarini, S., Agostini, S., Doglioni, C., Innocenti, F., Manetti, P., 2007. Evidence for serpentinite fluid in convergent margin systems: the example of El Salvador (Central America) arc lavas. Geochem. Geophys. Geosyst. 8, Q09014. https://doi.org/10.1029/ 2006GC001508.

US EPA, 2001. National Primary Drinking Water Standards. United States Environmental Protection Agency (EPA 816-F-01-007).

Varekamp, J.C., 2015. The chemical composition and evolution of volcanic lakes. In: Rouwet, D., Christenson, B., Tassi, F., Vandemeulebrouck, J. (Eds.), Volcanic Lakes, Advances in Volcanology. Springer-Heidelberg, pp. 93-123 https://doi.org/10.1007/9783-642-36833-2 2 .
Varekamp, J.C., Kreulen, R., 2000. The stable isotope geochemistry of volcanic lakes, with examples from Indonesia. J. Volcanol. Geotherm. Res. 97, 309-327.

Vaselli, O., Tassi, F., Montegrossi, G., Capaccioni, B., Giannini, L., 2006. Sampling and analysis of fumarolic gases. Acta Vulcanol. 1-2, 65-76.

Venturi, S., Tassi, F., Bicocchi, G., Cabassi, J., Capecchiacci, F., Capasso, G., Vaselli, O., Ricci, A. Grassa, F., 2017. Fractionation processes affecting the stable carbon isotope signature of thermal waters from hydrothermal/volcanic systems: the examples of Campi Flegrei and Vulcano Island (southern Italy). J. Volcanol. Geotherm. Res. 345, 46-57.

Walther, C.H.E., Flueh, E.R., Ranero, C.R., von Huene, R., Strauch, W., 2000. Crustal structure across the Pacific margin of Nicaragua: evidence for ophiolitic basement and a shallow mantle sliver. Geophys. J. Int. 141 (3), 759-777.

Webster, J.G., Nordstrom, D.K., 2003. Geothermal Arsenic. The source, transport and fate of arsenic in geothermal systems. In: Welch, A.H., Stollenwerk, K.G. (Eds.), Arsenic in Groundwater: Geochemistry and Occurrence. Kluwer Academic Publishers, pp. 101-126.

Weiss, R., 1970. The solubility of nitrogen, oxygen and argon in water and seawater. Deep-Sea Res. 17, 721-735.

WHO, 2003. Boron in drinking-water. Background Document for Development of WHO Guidelines for Drinking-water Quality. World Health Organization, Geneva, Switzerland.

Wilhelm, E., Battino, R., Wilcock, R.J., 1977. Low-pressure solubility of gases in liquid water. Chem. Rev. 77 (2), 219-262.

Zehnder, A.J.B., 1978. Ecology of methane formation. In: Michell R (ed) Water Pollution Microbiology. Wiley, New York, pp. 349-376.

Zhang, J., Quay, P.D., Wilbur, D.O., 1995. Carbon isotope fractionation during gas-water exchange and dissolution of $\mathrm{CO}_{2}$. Geochim. Cosmochim. Acta 59, 107-114.

Zimmer, M., Tassi, F., Vaselli, O., Kujawa, C., Cabassi, J., Erzinger, J., 2015. The gas membrane sensor (GMS) method: a new analytical approach for real-time gas concentration measurements in volcanic lakes. Geol. Soc. Lond., Spec. Publ. 437 (1), 223-232. 